\title{
Type-1 Cannabinoid Receptor Signaling in Neuronal Development
}

\author{
Anne-Lise Gaffuri Delphine Ladarre Zsolt Lenkei \\ Neurobiology Laboratory, ESPCI-ParisTech, ESPCI-CNRS UMR 7637, Paris, France
}

\section{Key Words}

GPCR $\cdot$ Brain development $\cdot$ Neuritogenesis $\cdot$ Axonal tracts of cytoskeletal effectors, which act in concert with positivefeedback local-excitation loops, to ultimately yield highly polarized neurons.

Copyright $\odot 2012$ S. Karger AG, Basel

\begin{abstract}
The type-1 cannabinoid receptor (CB1R) was initially identified as the neuronal target of $\Delta^{9}$-tetrahydrocannabinol (THC), the major psychoactive substance of marijuana. This receptor is one of the most abundant G-protein-coupled receptors in the adult brain, the target of endocannabinoid ligands and a well-characterized retrograde synaptic regulator. However, CB1Rs are also highly and often transiently expressed in neuronal populations in the embryonic and early postnatal brain, even before the formation of synapses. This suggests important physiological roles for CB1Rs during neuronal development. Several recent reviews have summarized our knowledge about the role of the endocannabinoid (eCB) system in neurodevelopment and neurotransmission by focusing on the metabolism of endocannabinoid molecules. Here, we review current knowledge about the effects of the modulation of CB1R signaling during the different phases of brain development. More precisely, we focus on reports that directly implicate CB1Rs during progenitor cell migration and differentiation, neurite outgrowth, axonal pathfinding and synaptogenesis. Based on theoretical considerations and on the reviewed experimental data, we propose a new model to explain the diversity of experimental findings on $\mathrm{eCB}$ signaling on neurite growth and axonal pathfinding. In our model, cell-autonomus and paracrine eCBs acting on CB1Rs are part of a global inhibitory network
\end{abstract}

\section{Introduction}

The main neuronal receptor for $\Delta^{9}$-tetrahydrocannabinol (THC), the major psychoactive substance of marijuana, is the type-1 cannabinoid receptor (CB1R), one of the most abundant G-protein-coupled receptors (GPCRs) in the nervous system [1]. The endogenous ligands of CB1R, i.e. endocannabinoids (eCBs), are currently recognized as retrograde messengers that are capable of modulating synaptic plasticity at different time scales. First, short-term forms of eCB-mediated suppression of synaptic transmission, called depolarizationinduced suppression of inhibition (DSI) or excitation (DSE), are induced by a transient stimulation of CB1Rs which inhibits voltage-gated calcium channels leading to the inhibition of neurotransmitter release [2]. Second, the autocrine activation of CB1R can lead to synaptic slow self-inhibition (SSI) that lasts around $20 \mathrm{~min}$, where the receptor modulates calcium-dependent potassium conductance [3]. Finally, eCB signaling mediates long-term synaptic depression (LTD) in excitatory and inhibitory

\section{A.-L. Gaffuri and D. Ladarre contributed equally to this work.}

\section{KARGER}

Fax +41613061234 E-Mail karger@karger.ch www.karger.com

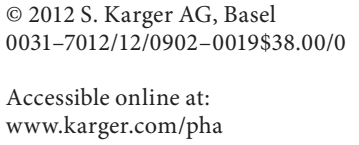


afferents. Extended activation (several minutes) of presynaptic CB1Rs coupled to pre- and/or postsynaptic activation leads to a decrease of presynaptic PKA (protein kinase A) activity, via the activation of $G_{i / o}$ proteins that inhibit adenylyl cyclase. This results in dephosphorylation of target proteins and a long-lasting reduction of neurotransmitter release (recently reviewed in Heifets and Castillo [4]).

In addition to these now relatively well-characterized functions, in the last two decades it became widely recognized that $\mathrm{eCB}$ actions in the brain are not limited to the regulation of neurotransmission at established adult synapses. Developmental studies have shown that, from zebrafish to mammals, CB1R is highly expressed in the developing brain [5-11]. Remarkably, after birth, when synaptic contacts of axons consolidate, CB1R expression is greatly reduced in structures such as cortical projection neurons $[7,8,12]$. This peculiar expression pattern opens the possibility that neuronal eCBs may play important novel roles, different from their established roles in synaptic regulation. Indeed, currently eCBs and $\mathrm{CB} 1 \mathrm{R}$ are known to be involved in brain development at the synaptic [7, 12-15], neuronal [7-12, 15-19] and network level [5, $10,20]$.

The main purpose of this review is to summarize current knowledge about the effects of CB1R signaling during different phases of brain development. More precisely, we will focus on studies reporting the direct effects of $\mathrm{CB} 1 \mathrm{R}$ during migration and differentiation of progenitor cells, neurite outgrowth, axonal pathfinding and synaptogenesis. As the exact role of CB1Rs in several of these functions is still controversial, we have attempted to precisely summarize experimental data and to consider whether a consensus model could be proposed.

\section{The Type-1 Cannabinoid Receptor CB1R}

Cloned in 1990, the CB1R was established as the target of $\Delta^{9}$-tetrahydrocannabinol, the major psychoactive substance of marijuana [1], and as the main neuronal receptor of the eCB system. CB1R is a class A or rhodopsin-like, seven-transmembrane-domain GPCR. CB1Rs are predominantly coupled to $G$ proteins of the $\mathrm{G}_{\mathrm{i} / \mathrm{o}}$ family, consequently CB1R activation leads in most tissues to inhibition of adenylate cyclase, resulting in diminished production of cAMP and protein kinase A (PKA) as well as in activation of G-protein-coupled inwardly rectifying potassium channels (GIRKs), in the inhibition of several types of voltage-gated calcium channels, and in the activation of the ERK 1/2, p38 MAPK and JNK pathways (for a recent review on CB1R signaling in nonpolarized cells, see Turu and Hunyady [21]). In neurons, CB1Rs were generally reported to couple to similar signaling pathways [22-24] as in nonpolarized cells, but we do not yet know how the specific neuronal structure, such as the unusually high surface-to-volume ratio of mature axons, modifies CB1R signaling. Furthermore, direct information about the mobilization of CB1R effectors in developing neurons is still sparse.

GPCRs are highly dynamic sensory molecules, displaying a flexible and dynamic three-dimensional structure. Evidence from both functional and biophysical studies suggests that GPCRs permanently sample multiple conformations but are held in a basal conformational equilibrium at steady state by intervening loops and noncovalent intramolecular interactions [25] such as the highly conserved 'ionic lock' between the $3 \mathrm{rd}$ and 6th transmembrane domains (reviewed in refs. [25-28]). Agonist binding modifies the energy landscape and leads to a prolonged adoption of an active receptor conformation, resulting in the rearrangement of the cytoplasmic domain of the receptor and in subsequent mobilization of intracellular signaling pathways mainly through a cognate heterotrimeric G-protein. Agonist ligands shift the equilibrium toward activated states, whereas inverse agonists shift the equilibrium toward inactive states. Signaling by stabilized activated states is typically terminated on the timescale of seconds by phosphorylation of specific intracellular serine and threonine residues, which leads to decoupling from effectors (desensitization) and to the recruitment of scaffolding proteins such as $\beta$-arrestins, ultimately resulting in GPCR endocytosis through the classical clathrin-mediated endocytic pathway. After endosomal elimination of bound ligands and dephosphorylation, GPCRs are either recycled back to the plasma membrane or degraded in lysosomes, depending on the receptor subtype, the cell type and the level of activation.

Interestingly, the CB1R, like numerous other GPCRs [29], displays a high level of constitutive activity, i.e. constitutive activation of intracellular signaling pathways in absence of exogenous ligands, either when heterologously expressed in non-neuronal cells [30] or in neurons where CB1Rs are endogenous [31, 32]. The cannabinoid receptor family shares the highly conserved DRY motif as well as several neighboring residues with the GPCR consensus sequence [33]. However, Debra Kendall's group has observed that all cannabinoid receptors identified to date differ from the consensus GPCR sequence by a Thr substitution at position 3.46 as well as one helical turn amino-terminal to Arg 3.50, which is part of the basal- 
state stabilizing, highly-conserved ionic lock. Substitution of Thr 3.46 with Ala, a residue with a higher helical packing moment, resulted in a receptor (T210A) with diminished constitutive activity [34].

Interestingly, while $\mathrm{CB} 1 \mathrm{R}$ receptors are localized to the plasma membrane in axons of mature neurons [35-38], a predominantly intracellular localization was reported in nonpolarized cells $[34,39-44]$ and in the somatodendritic domain of mature neurons $[35-38,45]$ as well as in the somatodendritic and axonal domain of embryonic neurons [8]. The exact origin and role of this intracellular CB1R population is not settled yet $[43,46]$. We have previously reported that an important proportion of intracellular CB1Rs are localized to endosomes, that a significant proportion of intracellular CB1Rs is of endocytic origin $[38,39]$, and that the constitutive endocytosis of CB1Rs is necessary for the correct axonal targeting of CB1Rs $[38,45]$, by a mechanism similar to that of the constitutively active $5-\mathrm{HT}_{1 \mathrm{~B}}$ serotonin receptor [47]. Blockade of constitutive activation, either through the T210A mutation [34], inverse agonist treatment [38,39] (but see McDonald et al. [45]) or reduction of steady-state cellautonomous production of eCB 2-arachidonoylglycerol (2-AG) [48] reduced the endosomal CB1R population suggesting that constitutive endocytosis is a consequence of constitutive CB1R activation at steady state. These results are in line with the view that an important intracellular pool, reported also for several constitutively active GPCRs [49-56], is a dynamic phenomenon and is related to constitutive activation of CB1Rs. However, as detailed below, in addition to putative structural determinants, eCBs, which are ubiquitously expressed in neurons [57], may contribute to constitutive activation of CB1Rs.

\section{eCBs Are Ubiquitous Neuronal Membrane Components}

eCBs are lipophilic molecules, which are thought to be synthesized on demand from ubiquitous plasma membrane components through multiple biosynthetic pathways, in response to elevations of intracellular calcium alone or combined with activation of several $G_{\mathrm{q} / 11}$-protein-coupled receptors (for recent detailed reviews, see references $[58,59])$. The first of these eCBs to be identified were $\mathrm{N}$-arachidonoylethanolamine, also called anandamide (AEA) [60] and 2-arachidonoylglycerol (2-AG) [61], both belonging to the eicosanoid family of poly-unsaturated fatty acids. AEA is synthesized mainly by hydrolysis of the corresponding $\mathrm{N}$-acyl-phosphatidyletha- nolamines (NAPEs), by a phospholipase D selective for NAPEs (NAPE-PLD). AEA is inactivated by hydrolysis by the fatty acid amine hydrolase (FAAH). The other major endocannabinoid, 2-AG, is synthesized principally by hydrolysis from diacylglycerols (DAGs) containing arachidonate in position 2 . This reaction is catalyzed by two isoforms of DAG lipases (DAGL $\alpha$ and DAGL $\beta$ ) selective for the sn-1 position. The degradation of 2-AG is mainly due to monoacylglycerol lipases (MAGLs). Other members of the eicosanoid family are also synthesized in neurons and are able to bind the CB1R: dihomo- $\gamma$-linolenoyl ethanolamide and docosatetraenylethanolamide. Several other arachidonic-acid-derived molecules showing eCB activity have been identified: the 2-arachidonoylglyceryl ether (or noladin ether), the $\mathrm{O}$-arachidonoylethanolamine (virhodamine) and the $\mathrm{N}$-arachidonoyldopamine (NADA) (for review, see Bisogno et al. [62]).

While synthesis and degradation of the major eCBs AEA and 2-AG are now relatively well understood, storage and release mechanisms are not well known (for a recent review, see Alger and Kim [59]). Notably, it appears that significant amounts of $2-\mathrm{AG}$ are present in resting neurons, that only a fraction of stimulation-induced 2-AG is released from cells and that basal levels of AEA are sufficient to constitutively induce CB1R signaling [59]. We have also shown previously that basal levels of 2-AG are sufficient to tonically activate CB1Rs in nonstimulated neurons [48]. Given that eCB ligands are directly derived from membrane phospholipids, and that no effective intramembrane sequestration of the important basal pool of eCBs has been identified yet, it is highly probable that eCBs may reach the membrane-bound CB1Rs by two-dimensional diffusion, leading to cell-autonomous basal (i.e. constitutive) activation of CB1Rs. Indeed, the possibility of this direct entry of eCBs from the lipid bilayer to the CB1R-binding site was recently confirmed by biochemical tools as well as molecular simulation (reviewed in Howlett et al. [57]). As seen above, CB1Rs display structural characteristics [63] that may contribute, in addition to the ubiquitously present endocannabinoid molecules, to the well-described constitutive stimulation of downstream-signaling pathways in absence of exogenous cannabinoid ligands [57, 64]. The idea that membrane bilayer composition may have significant effect on the conformation of embedded GPCRs was first described by studying the effect of membrane cholesterol content on rhodopsin activation and has been extended since to other GPCRs and lipids (recently reviewed in Oates and Watts [65]). In general, cell membranes are increasingly considered as key dynamic com- 
ponents in sensory and signaling pathways, where the highly regulated lipid environment significantly regulates the structure, conformation and function of embedded proteins [66]. Thus, a plausible scenario proposes that CB1Rs, due to structural determinants and the presence of specific binding sites which are accessible for lipids present in the lipid bilayer, are able to continuously translate the plasma membrane concentration of highly regulated lipidic eCBs into the activation of specific intracellular signaling pathways, and be the subject of steadystate endocytosis. The source of eCBs acting on CB1Rs may be in many instances cell-autonomous. In the endocannabinoid literature, this cell-autonomous action is often referred to as 'autocrine'. However, as seen above, lipophilic eCBs likely do not need to leave the neuronal plasma membrane to gain access to the ligand binding site of CB1Rs on the same neuron as proposed by the classical autocrine model (from Greek krīnō, 'to separate' or 'to secrete') where hormones or chemical messengers are secreted to bind to receptors on the same cell. In addition to the cell-autonomous mode of CB1R activation, a large body of indirect experimental evidence, gathered using electrophysiological, anatomical and genetic tools suggest that eCBs may be able to leave the parent cell membrane and cross short distances in the aqueous extracellular milieu, leading to paracrine activation of CB1Rs on neighboring neurons, leading to the well-described retrograde modulation of synaptic transmission in the adult brain [2].

Taken together, the lack of clearly understood storage and release mechanisms for eCBs, as well as the structural characteristics of CB1Rs, the high level of cellular eCB content in membranes of non-stimulated neurons, the multiple reports on cell-autonomous CB1R activation mechanisms and high level of CB1Rs outside of presynaptic specializations [67], suggest that in addition to the classical modus operandi of presynaptic GPCR function [68], novel functional paradigms should also be envisioned for CB1Rs, both in the adult and developing brain.

\section{CB1Rs and eCBs Are Highly Expressed in the Developing Brain}

$\mathrm{CB} 1 \mathrm{R}$ is one of the most abundant GPCRs expressed in the adult brain [69]. However, CB1Rs are also highly expressed from early fetal stages, starting from embryonic day 12.5 (E12.5) in mice [8]. First, autoradiography using radiolabeled cannabinoid ligands showed that $\mathrm{CB1R}$ is highly expressed in white matter areas at late fe- tal stages (E21) and that its expression is downregulated after birth leading to a disappearance of significant CB1R binding in these structures (corpus callosum, fornix, stria terminalis, stria medullaris and fasciculus retroflexus) [70]. On the other hand, at fetal stages, CB1R is already expressed in structures such as hippocampus, cerebellum, caudate-putamen and cerebral cortex, and its expression increases to adult levels after birth. Moreover, stimulation of $\left[{ }^{35} \mathrm{~S}\right] \mathrm{GTP} \gamma \mathrm{S}$ binding by cannabinoid agonists suggests that embryonic CB1Rs are already functional [71].

Following the identification of the CB1R gene [1], in situ hybridization histochemistry was used to determine the localization of the corresponding mRNA transcript in both fetal and adult rodent brains. CB1R mRNA was identified in structures such as cerebral cortex, hippocampus, caudate-putamen and cerebellum at E16 [71]. Interestingly, CB1R binding and mRNA expression patterns are mismatched in white matter areas of fetal brains, as CB1R binding is elevated whereas mRNA expression is low [72]. The limited spatial resolution of receptor autoradiography and in situ hybridization initially precluded to determine whether the transiently elevated CB1R expression in white matter areas, which are composed mainly of axons of projection neurons, is due to axonally transported CB1Rs or to local expression in astrocytes. This question was finally settled by using immunohistochemistry, which showed that most CB1Rs present in fetal white matter areas are located in axons of projection neurons in contrast with the adult brain, where CB1R is predominantly expressed in GABAergic interneurons. Thus, several groups, including ours, showed that CB1R is highly expressed in glutamatergic projection neurons from E12.5 and is downregulated in these neurons at approximately 5 days after birth (P5) [7, 8, 12]. Moreover, immunochemistry allowed CB1R to be localized with high resolution by electron microscopy. In contrast to the adult brain, where CB1R is located on the axonal plasma membrane and in somatodendritic endosomes $[36,73]$, in the fetal brain, CB1R is mostly localized to endosomes both in axons and in the somatodendritic region [8].

\section{eCB Signaling Modulates Progenitor Cells Migration and Differentiation}

One of the most remarkable natural phenomena is the emergence of the highly complex vertebrate brain, which is accomplished by an extraordinary succession of selforganized developmental events and finely tuned through 
experience. Initial establishment of functional structure and connectivity in the developing cerebral cortex rely upon three major, self-organized early developmental events: (1) the proliferation and differentiation of neural progenitors, leading to the timely generation of appropriate neuronal subtypes, (2) the migration of neurons to specific locations, and (3) the establishment of functional synaptic connections between neurons after completing neuronal differentiation [74].

Using rodent models, CB1Rs were detected in embryonic $[75,76]$ and postnatal neuronal progenitors [77-79], suggesting a developmental role for the eCB system starting at the earliest stages of brain development. Indeed, studies in the last decade have established the implications of CB1R in the survival, proliferation, migration and differentiation of neuronal progenitors (table 1).

Studies of the effects of cannabinoids on the survival of neuronal progenitors have been attempted with various CB1R agonists and produced conflicting results: ACEA (arachidonyl-2-chloroethylamide, an AEA analog) and HU-210 ((-)-1,1-dimethylheptyl analog of 11-hydroxy- $\Delta^{8}$-tetrahydrocannabinol) two agonists of CB1R, enhanced progenitor survival [80, 81], whereas URB297, a FAAH inhibitor, AEA and THC seemed to have no effect $[79,81,82]$. On the other hand, WIN55,212-2, an other agonist of CB1R, did not influence the survival of neuronal progenitors from cortices [79] but enhanced oligodendrocyte progenitor survival through activation of $\mathrm{G}_{\mathrm{i} / \mathrm{o}}$ proteins, enhanced PI3K (phosphoinositide 3-kinase) activity and Akt (protein kinase B) phosphorylation [80].

In vitro, pharmacological CB1R activation enhances progenitor proliferation and neurosphere generation via activation of $\mathrm{G}_{\mathrm{i} / \mathrm{o}}$ proteins and ERK phosphorylation. This mechanism does not involve the PI3K/Akt pathway [78]. On the contrary, application of the antagonist/inverse agonist SR141716 leads to a decrease of progenitor proliferation [76, 78]. The presence of this proliferative effect has not yet been unambiguously shown in vivo. Studies on CB1R knock-out mice indicate indeed a decrease of neuronal progenitor proliferation [77] and FAAH knock-out mice show also an increase of progenitor proliferation [76]. Chronic treatment with the cannabinoid agonist HU-210 also led to an increase in progenitor proliferation [78]. However, mice treated with THC or cannabidiol during 6 weeks had a lower number of proliferating cells in the dentate gyrus in comparison with the controls [81], which is reminiscent of previous findings of reduced progenitor cell proliferation in vitro following an elevated dose of AEA [82].

CB1R Signaling in Neuronal

Development
The effect of CB1Rs to regulate the ability of neuronal progenitors to differentiate and reach mature neuronal phenotype has been evaluated in various studies. In 2002, Rueda et al. [75] showed that AEA inhibits differentiation of cortical neuron progenitor and NGF-induced PC12 cells via CB1R-dependent ERK activation. They also found that administration of methanandamide, an ana$\log$ of AEA, decreases the number of new mature neurons in the dentate gyrus of rats, whereas the antagonist SR141716 increases neurogenesis in the same zone. Another study has shown that CB1R activation promotes the differentiation of neuronal progenitors into astroglial cells, confirmed by the higher presence of these cells in FAAH knock-out mice and the lower level of differentiated cells in CB1R knock-out mice [79]. Chronic treatment with the cannabinoid agonist HU-210 did not lead to an increase in neuronal differentiation of newly-born progenitors [78]. Interestingly, a recent study indicates that, in vitro, a 4-day treatment of AEA promotes glial differentiation, whereas a 7-day treatment promotes neuronal differentiation [82]. By studying adult spinal cord progenitors in primary cultures and in vitro slices, the knock-down of CB1Rs and treatment with the antagonist AM-251 resulted in enhanced neuronal differentiation [83].

Finally, pharmacological activation of CB1R increases migration of GABAergic interneurons both in vitro and in vivo through a mechanism involving the activation of TrkB receptor (BDNF/NT-3 growth factor receptor) [18], whereas inhibition of CB1Rs decreases neuroblast migration in rostral migratory stream explants [84].

Overall, in spite of the rather moderate expression levels in neuronal progenitors as compared to embryonic projection neurons (fig. 1) [8] or adult GABAergic neurons, CB1Rs appear to regulate survival, proliferation, migration and differentiation of neuronal progenitors. The overall picture that seems to emerge from the above studies is that CB1R activation promotes the proliferation, survival and migration of progenitor cells but delays the transition from the multipotent, proliferating and migration-competent progenitor phenotype towards a settled, well-differentiated, postmitotic neuronal phenotype. However, the duration of the treatment and the presence of growth-promoting factors may modulate this effect. Notably, long-term treatment was reported in several instances to yield the opposite effects of short-term treatment $[81,82]$. Thus, further investigation is required to clarify the validity of the above results in both embryonic and post-natal physiological settings. Specific intracellular signaling mechanisms have also yet to be identi- 
Table 1. Effects of CB1R activation (a) or inactivation (b) on progenitor cell survival, proliferation, migration and differentiation a CB1R activation

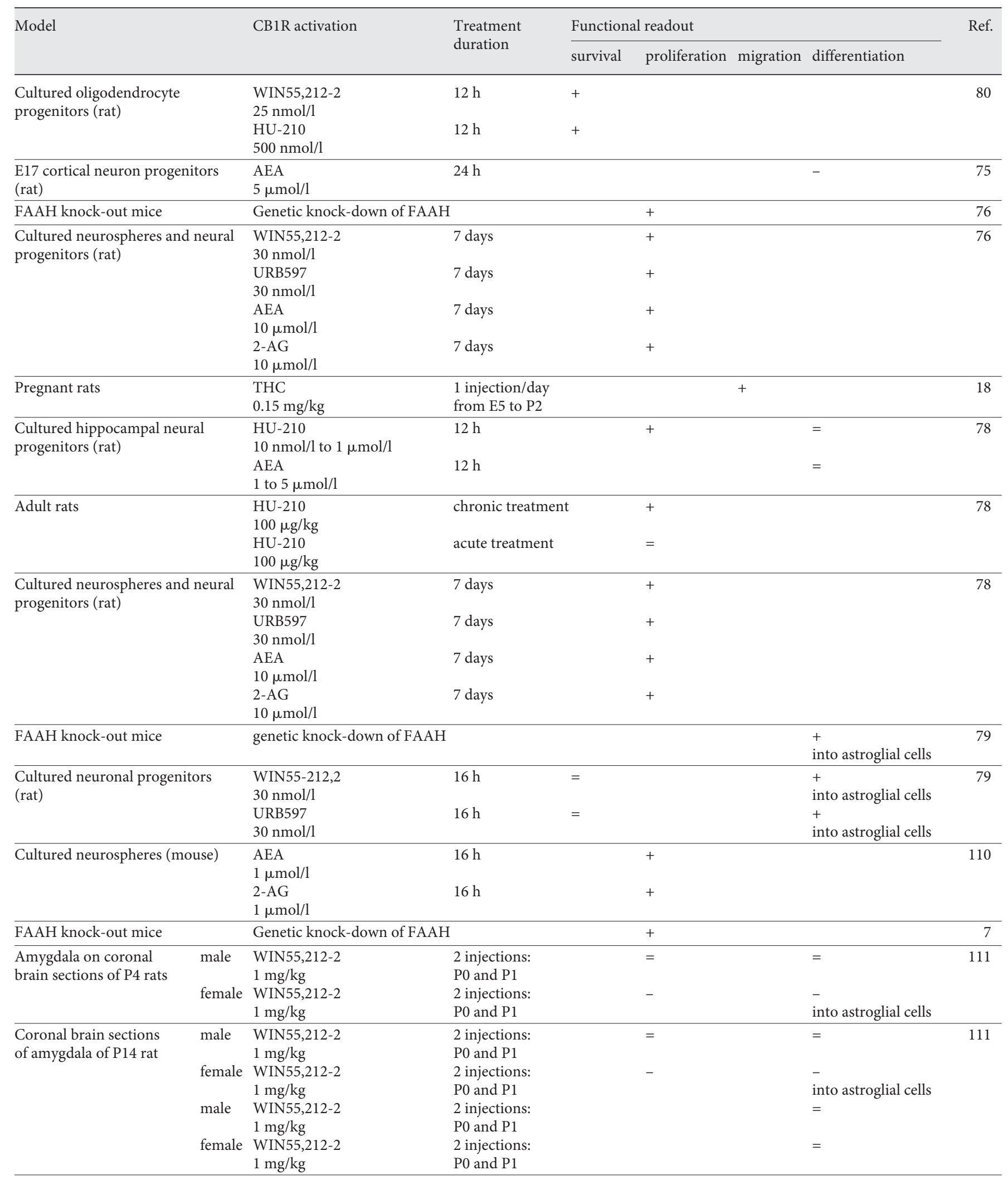


Table 1 (continued)

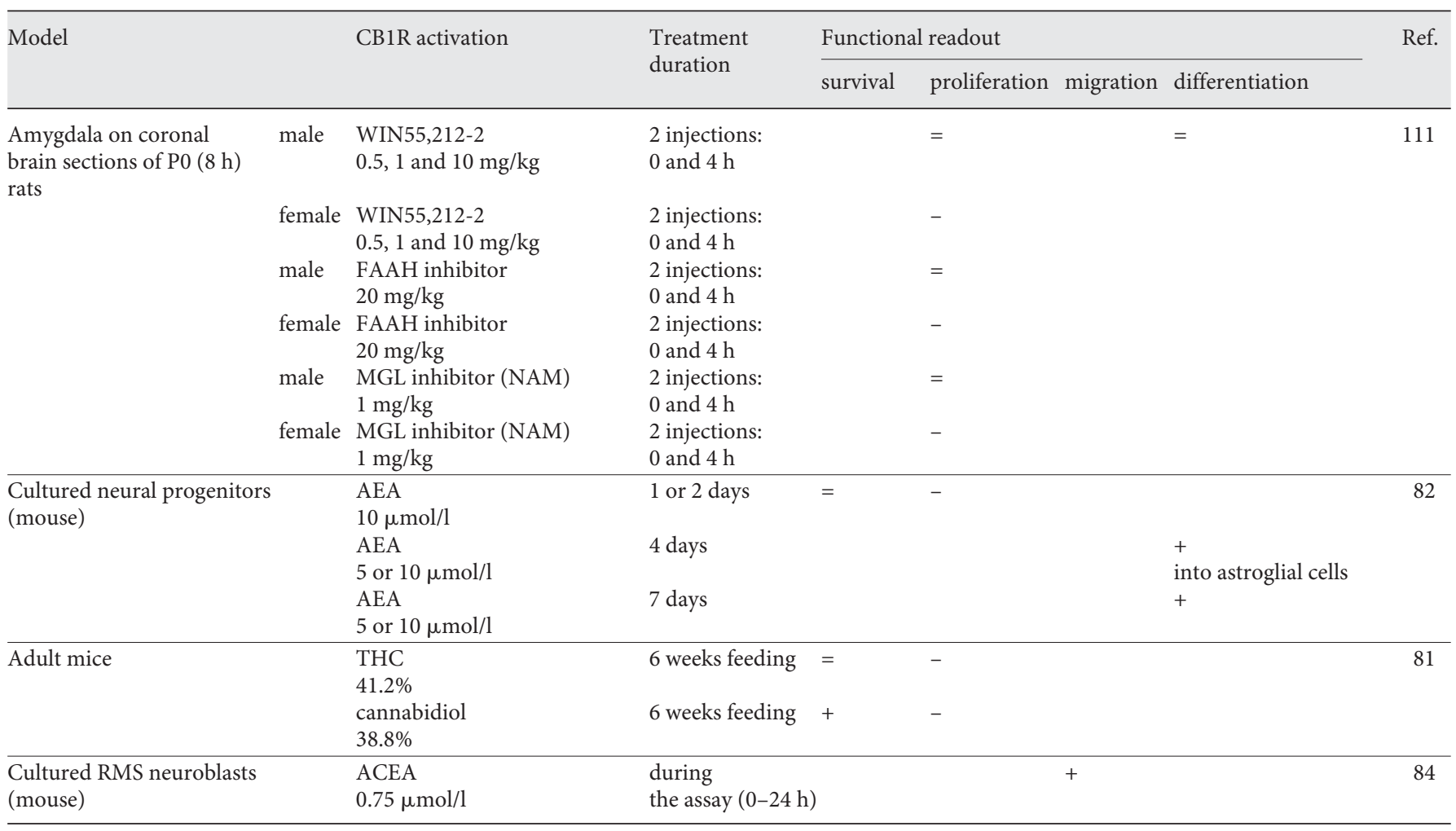

b CB1R inactivation

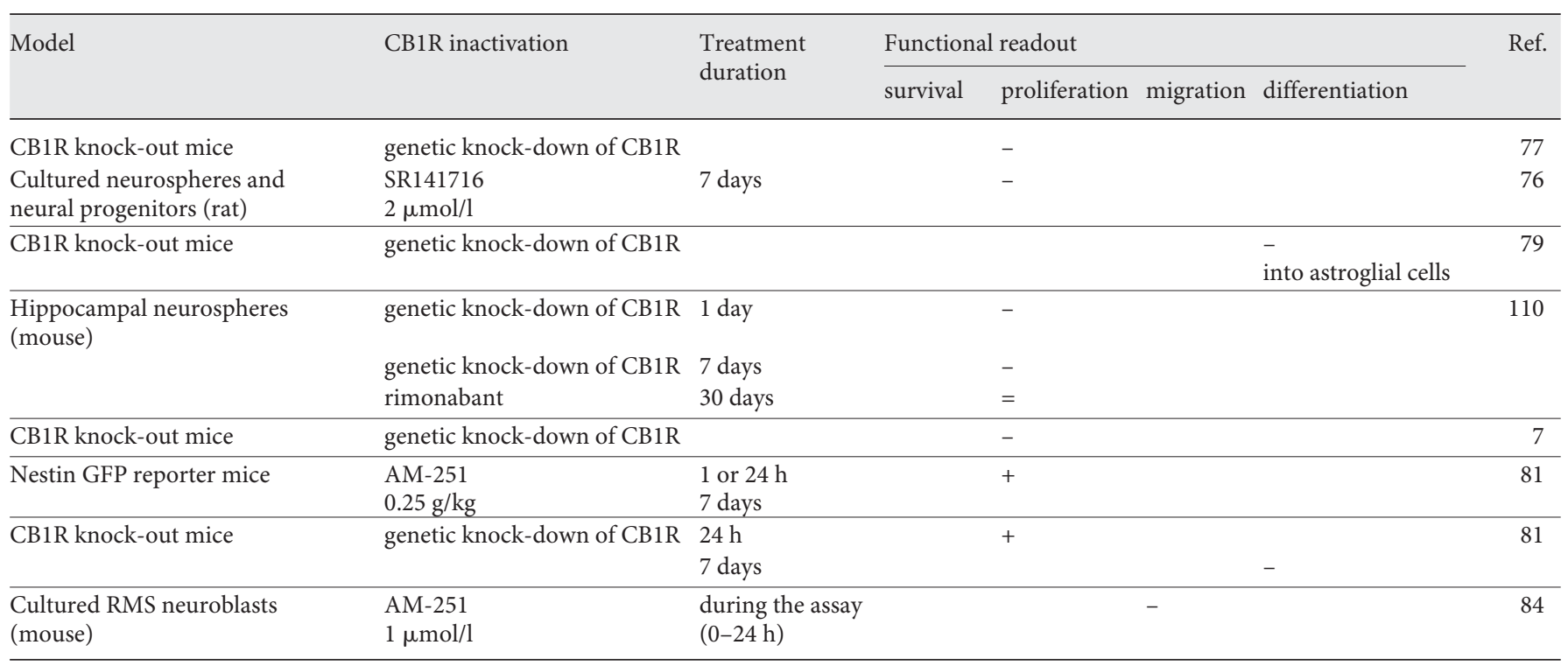

This table summarizes the effects of direct modulation of CB1R activity on progenitor cell survival, proliferation, migration and differentiation. The ' + ' and '-' signs represent, respectively, statistically significant increase or decrease of the measured parameter, whereas a ' $=$ ' sign means no modification as compared to control. The mentions '+ into astroglial cells' and '- into astroglial cells' in the column named 'differentiation' mean that the modulation of CB1R activity activates or inhibits, respectively, the differentiation of progenitor cells into astroglial cells. 
Fig. 1. Overview of CB1R protein expression in the developing cortico-hippocampal formation of the mouse telencephalon at E13.5. Differentiating and migrating progenitors, located in the subventricular zone (svz) and in the ganglionic eminence (ge) do not express high levels of CB1Rs (red; colors refer to the online version only). However, CB1R is expressed by the majority of newly differentiated neurons of the early cortical plate (cp) as indicated by the co-expression of CB1R with the neuron-specific early-differentiation marker class III beta-tubulin (Tuj-1, arrows). As neurons mature, CB1R protein is gradually relocalized into growing axons of projection neurons (arrowheads). Thus, in the more mature lateral parts of the cerebral cortex (on the left-hand side), $\mathrm{CB} 1 \mathrm{R}$ immunolabeling is mainly localized in the intermediate zone, where Tuj-1-positive corticofugal axons are located. At the same time, in the less mature medial parts of the cortical region (right-hand side), which will later give rise to the hippocampus (hc), punctuate CB1R immunolabeling is localized to somatic endosomes of newly differentiated neurons, which lack axonal processes at this stage. Sections are counterstained for nuclei with DAPI (blue). Coronal section. $\mathrm{lv}=$ Lateral ventricle. Bar $=200 \mu \mathrm{m}$. For experimental details, refer to Vitalis et al. [8].

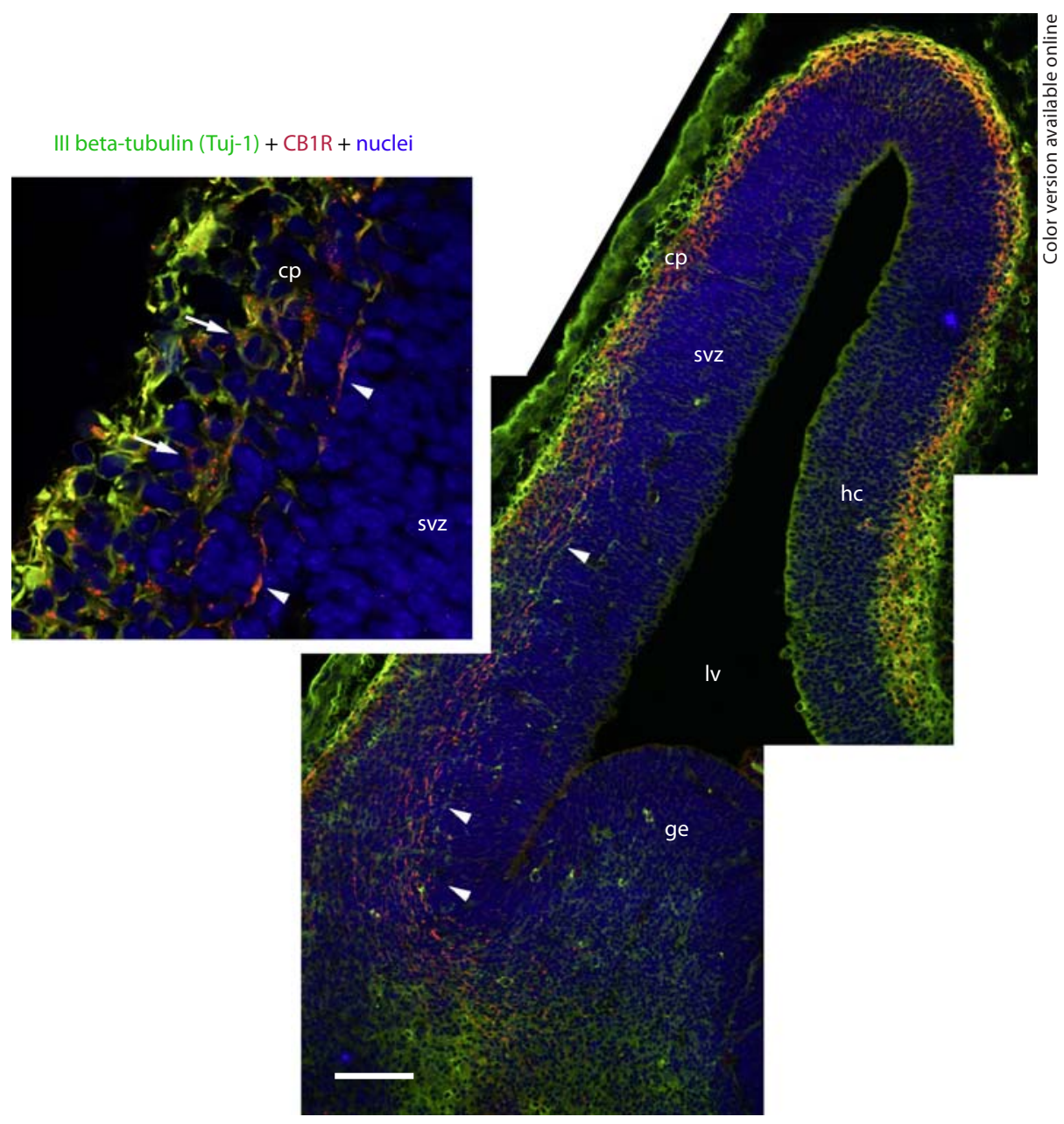

fied. As not all proliferating cells in a neurogenic niche become neurons [85], particular care must be taken in order to distinguish effects of CB1Rs on progenitor proliferation from their effects on neurogenesis.

\section{eCB Signaling as a Modulator of Neuritogenesis and Neurite Growth}

\section{CB1R Effects on Neurite Outgrowth:}

Neuroblastoma-Derived Cell Lines

One of the first steps of neuronal differentiation is neuritogenesis, i.e. the development of extensions, called neurites, which will differentiate into one axon and several dendrites, ultimately leading to a highly polarized mature neuron. Growing and manipulating well-polarized cultured primary neurons in a controlled environment is not an easily accessible experimental model.
However, immortalized neuronal cell lines, which are derived from neuroblastoma cells, are capable of long-term growth and generally represent a single cell type, providing a high degree of reproducibility. Therefore, they are widely used for studies that aim to better understand neuronal development and function. Consequently, the bulk of our initial knowledge on cannabinoid effects on neurite development was obtained by using immortalized neuronal cell lines, which in addition often express $\mathrm{CB} 1 \mathrm{R}$ receptors endogenously and may grow neurites in certain conditions (table 2). However, these neurites will not polarize into axons and dendrites, thus do not express key aspects of neuronal differentiation [86].

The first study of cannabinoid effects on neuronal cell morphology used rat B103 neuroblastoma cells and reported dose-dependent morphological changes following treatment with $\Delta^{9}$-THC at micromolar concentrations, such as cell rounding and retraction of neurites [87]. A 


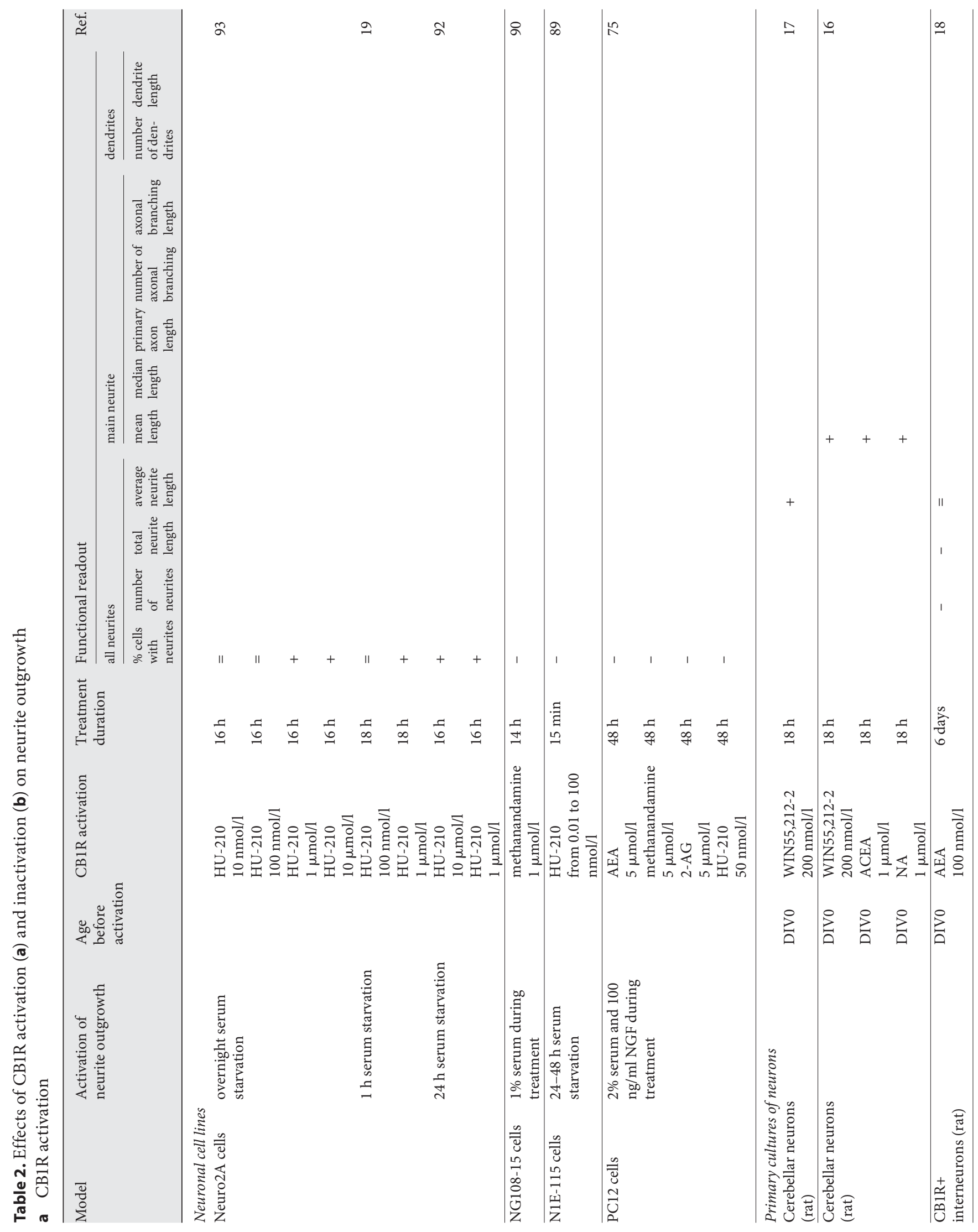




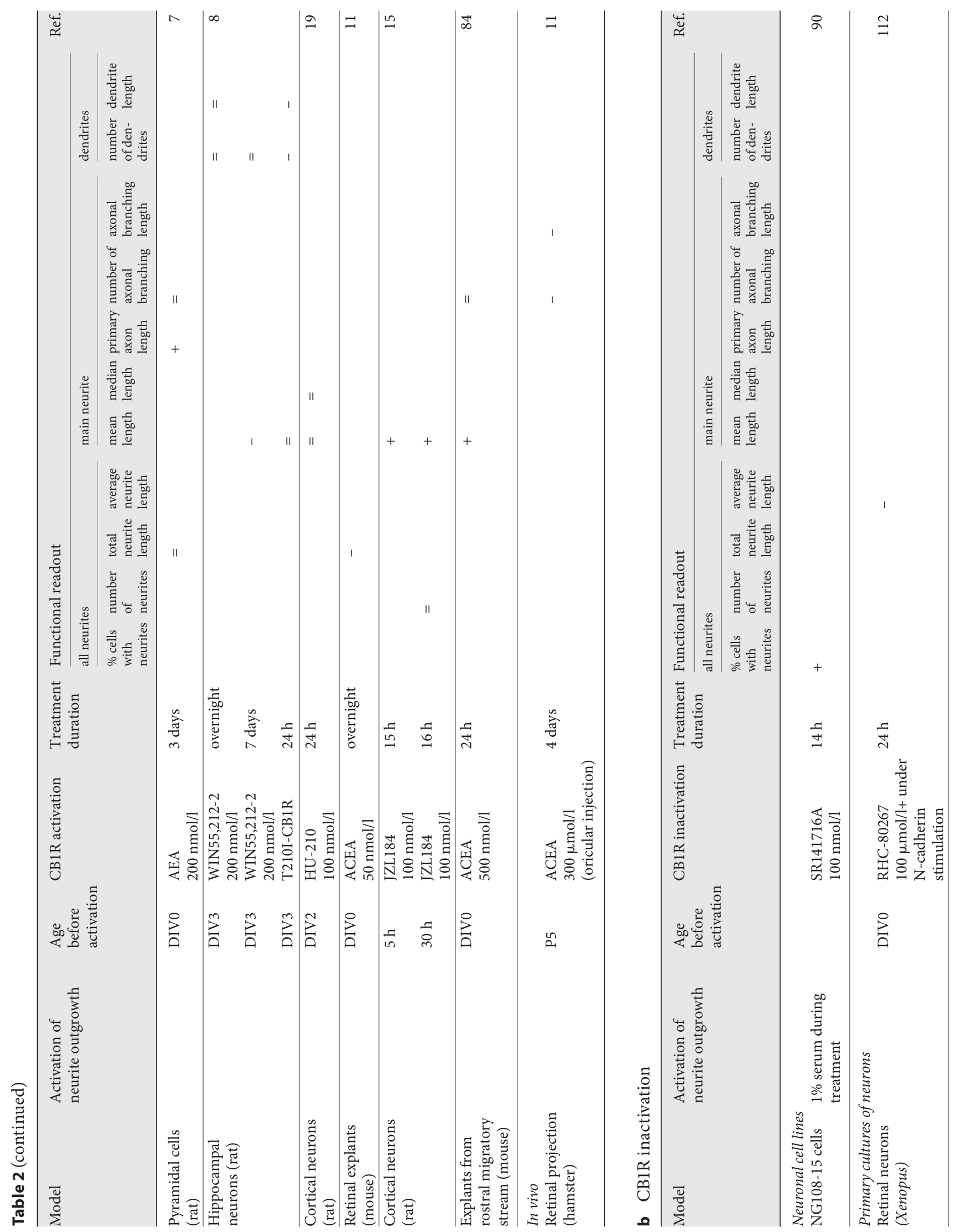




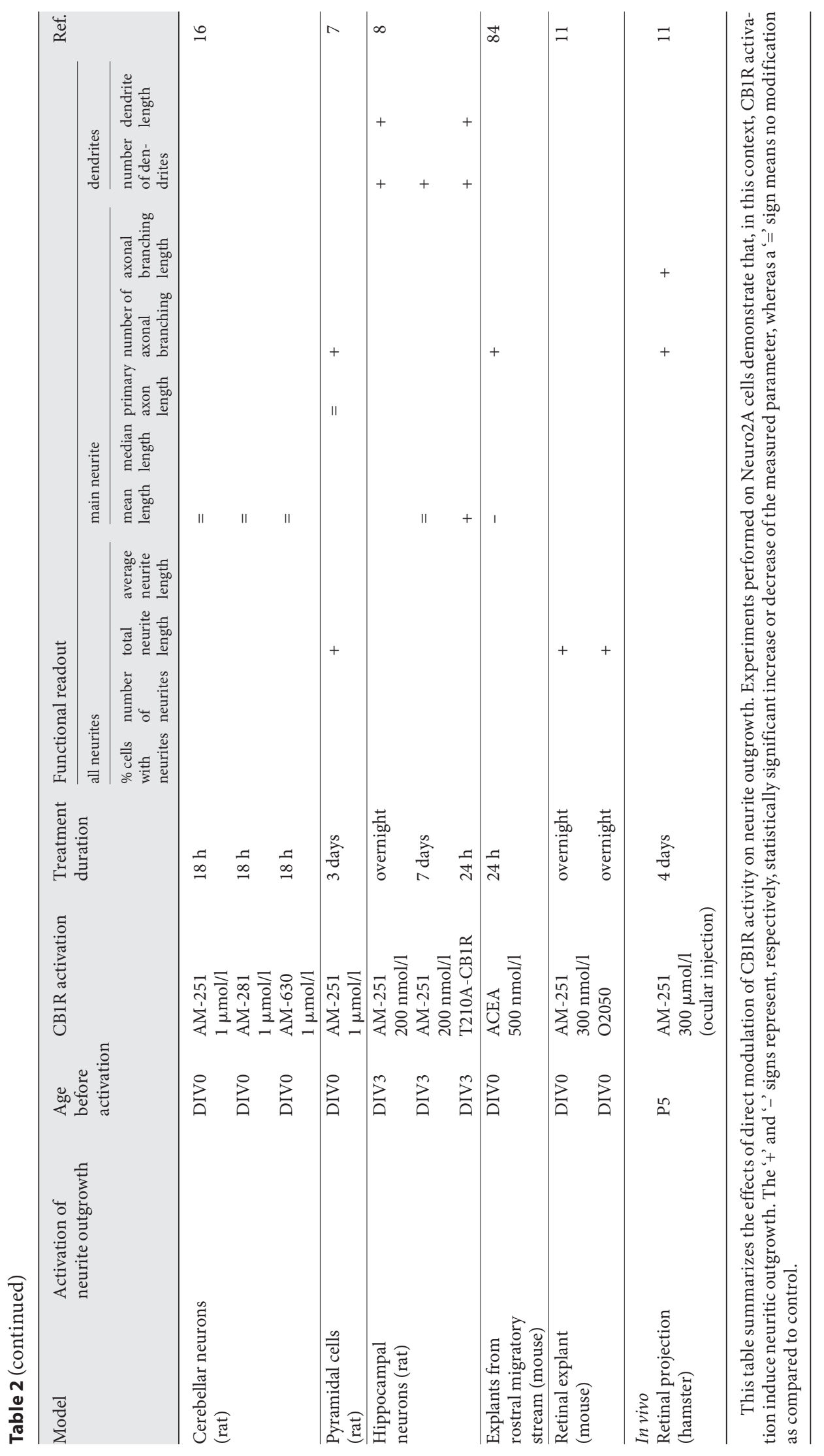


subsequent study also reported anandamide-induced cell rounding in CB1R-overexpressing B103 cells; this effect was PTX-insensitive and Rho-kinase dependent [88]. Similar effects were later reported in other neuroblastoma cell lines such as N1E-115 [89] and NG108-15 [90] and also in pheochromocytoma-derived, differentiating PC12 cells [75], by using either micromolar concentrations of the endocannabinoids AEA, methanandamine (mAEA) and 2-AG or nanomolar concentrations of the synthetic high-affinity agonist HU-210. Typically, treatment durations were between 14 and $48 \mathrm{~h}$, but the N1E115 cell study reported that cell-rounding and neurite retraction were already detectable after as little as $15 \mathrm{~min}$ of low-dose HU-210 treatment [89].

In contrast to these studies, which reported neurite retraction as a general effect following cannabinoid treatment, the group of Ravi Iyengar reported induction of neurite outgrowth in neuroblastoma-derived Neuro2A cells $[19,91-93]$. The underlying mechanisms reportedly involved the activation of CREB (cAMP response element-binding), which is activated by MAPK (mitogenactivated protein kinase), PAX6 (paired box protein-6), downstream of PI3K, and STAT3 (signal transducer and activator of transcription 3) which is regulated by Rap1 (Ras-related protein 1), Src (proto-oncogene tyrosineprotein kinase) and BRCA1 (breast cancer type 1 susceptibility protein). Interestingly, IL-6 can also activate STAT3 through Jak, and CB1R and IL-6 receptors are able to act in synergy to induce neurite outgrowth in Neuro2A cells at sub-threshold concentration of each agonist (HU210 and IL-6) [19]. These reports are intriguing for several reasons: (1) the main signaling pathway of CB1Rs is through $G_{\mathrm{o} / \mathrm{i}}$ proteins, which are usually negatively coupled to CREB activation, and (2) reported effects were achieved after long-term incubation, i.e. $16-18 \mathrm{~h}$, by using micromolar concentrations of the high-affinity ligand HU-210. Lower concentrations such as 10 and $100 \mathrm{nmol} / \mathrm{l}$ were ineffective. These results are intriguing since the dissociation constant $\left(\mathrm{K}_{\mathrm{d}}\right)$ of $\mathrm{HU}-210$ is $45 \mathrm{pmol} / \mathrm{l}$, so low-nanomolar concentrations are already saturating at CB1Rs. This raises the possibility that the reported induction of neurite growth, which is in variance with the above reports that used different neuroblastoma cell lines, may also be due to indirect effects of long-term, high-dose HU-210 treatment. In this context, it is of interest that the same group has recently demonstrated that neurite outgrowth induced by retinoic acid in Neuro2A cells is also achieved through an increased expression of both the DAGL $\alpha$ and DAGL $\beta$ diacylglycerol lipases, which synthesize 2-AG [91].

\section{CB1R Effects on Neurite Outgrowth: Primary Neuronal Cultures}

As with neuroblastoma-derived cell lines, the effects of CB1R activation or deactivation on neurite outgrowth in primary neuronal cultures are also somewhat controversial (table 2). Indeed, several studies found that CB1R activation promotes neurite outgrowth $[16,17,19]$, whereas others reported that similar treatments inhibit neurite development $[8,18]$ in cultured neurons.

On the one hand, neuronal CB1R has been described as an activator of a hierarchical signaling network that promotes neurite growth. First, Patrick Doherty's group, using cultured cerebellar granule neurons, demonstrated a positive effect of CB1R activation on neurite outgrowth [16]. They showed that cannabinoid receptor antagonists inhibit the axonal growth response induced by $\mathrm{N}$-cadherin and FGF2 (fibroblast growth factor 2), whereas CB1R agonist treatment mimics the N-cadherin/FGF2 responses. This modulation acts a step downstream of FGF receptor and upstream of calcium influx. The effect of CB1R activity on neurite outgrowth was further confirmed in another study from the same group [17], which showed that inhibiting DAGL $\alpha$ and DAGL $\beta$ by tetrahydrolipstatin reduces the neurite outgrowth response induced by FGF2. Finally, after reporting the coincidence between eCBs and IL-6 signaling in Neuro2A cells (see above), the team of Ravi Iyengar also demonstrated that co-incident stimulation of CB1R and the IL-6 receptor increases median length of neurites in rat primary cortical neurons [19].

On the other hand, when the group of Tibor Harkany addressed whether eCBs affect the morphological specification of CB1R expressing interneurons, they found that CB1R activation inhibits neurite extension by modulating TrkB receptor-dependent signaling [18]. They also showed that this negative effect of CB1R activation on neurite outgrowth (1) requires Src and MAPK activity, (2) is negatively regulated by PI3K (phosphatidylinositol 3 -kinase) and (3) is phospholipase C- $\boldsymbol{\gamma}$-kinase independent. These results partially contradict those obtained by Williams et al. [16], who could not find any evidence that $\mathrm{CB} 1 \mathrm{R}$ is coupled to the TrkB receptor to modulate neurite growth in cultured cerebellar granule neurons.

Finally, our group's observation of morphological changes of CB1R-transfected neurons in vitro indicate that $\mathrm{CB1R}$ is a predominantly negative regulator of neurite growth [8], since CB1R activation is inversely correlated with the total length of dendrites and axons. These results were obtained by two complementary techniques: pharmacological treatment of neurons expressing the 
wild-type CB1R or by transfection of point-mutant CB1Rs that display different levels of spontaneous activation, originally published by Kendall's group [34].

Finally, two recent studies $[7,84]$ performed on cultured mouse explants from rostral migratory stream and on cultured pyramidal cells, respectively, yielded results which allow consensus to be reached. On the one hand, Mulder et al. [7] showed that CB1R activation by AEA positively regulates axonal length; on the other, CB1R inactivation by AM-251 increases the number of axonal branching points. These results were consistent with those obtained on cultured mouse explants from the rostral migratory stream that demonstrated that inhibition of CB1R activity via AM-251 decreases the length of the main neurites while increasing the number of branching points [84]. Thus, these data suggest that the eCB system helps in maintaining a polarized morphology in growing neurons by promoting the extension of a single major leading process.

\section{CB1R Activity Modulates Targeting and Structure of Axonal Tracts}

During development, neurons extend axons in order to innervate their targets. Developing axons navigate through highly complex environments for long distances. This process has to be precisely controlled in order to obtain correct network architecture. Located at the tip of the growing axons, actin-rich growth cones are highly motile structures that explore the extracellular environments, determine the direction of growth, and guide axonal elongation.

CB1R is strongly expressed in projection axons during neuronal development of embryonic chicken $[5,6]$, zebrafish [6], mice $[7,8,10]$, rats [9] and in mouse retina [11]. Interestingly, this expression is dynamically regulated in cortical projection neurons during brain development $[6-8,12]$. Whereas projection neurons express only relatively low levels of CB1Rs in the adult hippocampus and cerebral cortex, these neurons express high amounts of functional CB1Rs during axonal elongation (between E12 and birth). After birth, when synaptic contacts consolidate, CB1R expression is gradually reduced in cortical projection neurons but remains highly expressed throughout adulthood in GABAergic interneurons.

Thus, after the discovery that CB1R expression is dynamically regulated in projection axons, several recent studies were devoted to investigate whether eCB signaling, through CB1R, exerts differential effects on axonal targeting in the developing brain (table 3). First, Watson et al. [6] have shown in chick and zebrafish embryos that modifying CB1R activity disrupts axonal projections and fasciculation. This effect was confirmed in the developing mammalian brain: genetic or pharmacological inactivation of embryonic CB1R leads to defasciculation and mistargeting of axonal tracts in rodents $[7,9,10]$. In the developing mouse brain, 2-AG appears to be the major $\mathrm{eCB}$ acting through $\mathrm{CB} 1 \mathrm{R}$ to modulate reciprocal connections between the thalamus and the cortex [10].

In order to precisely characterize how eCB signaling regulates axonal pathfinding, several studies have developed in vitro and in vivo approaches based on the direct observation of growth cone morphology, motility and directionality of growth. Indeed, in vitro observations clearly show that CB1R is present in growth cones and is particularly accumulated in filopodia [11, 12, 15, 37]. In vitro growth cone turning assays have allowed further understanding of the effects of local cannabinoid exposure on axonal navigation. Thus, anisotropic applications of CB1R agonists induce growth cone repulsion in rat and mouse CB1R-expressing cultured neurons [11, 12]. Similarly, CB1R agonists increase the frequency of electric field-induced cathodal repulsion in Xenopus laevis spinal neurons [12]. Furthermore, in mouse retinal explants cultures, constitutive CB1R activation has been shown to diminish the surface expression of the deleted in colorectal cancer receptor (DCC, a receptor for axonal guidance molecule netrin-1) in a PKA-dependent manner, thus opposing the growth-promoting effect of netrin-1, ultimately leading to growth cone retraction [11]. Thus, an increasing body of evidence suggests that CB1R signaling controls growth cone navigation by opposing attractive chemical and electrical directional cues, indicating an important role of eCB signaling in axonal pathfinding.

Using in vitro chemotropic growth cone turning assays, recent studies have started to characterize the molecular mechanisms underlying the effects of CB1R activation on growth cone navigation. Selective inhibition of ROCK (Rho-associated protein kinase) switched CB1R agonist induced neurite repulsion into chemoattraction without affecting neurite extension, indicating that in this process CB1R is coupled to the RhoA (Ras homolog gene family, member A) signaling pathway [12]. Moreover, the same group showed that agonist stimulation induces CB1R removal from the growth cone filopodia and Erk1/2 phosphorylation in the central growth cone domain. However, Argaw et al. [11] did not succeed in replicating these results using primary cortical glutamat- 
Table 3. Effects of CB1R activation (a) and inactivation (b) on axonal growth cones

a CB1R activation

\begin{tabular}{|c|c|c|c|c|c|c|c|c|c|}
\hline & \multirow[t]{2}{*}{ Cellular model } & \multirow{2}{*}{$\begin{array}{l}\text { DIV before } \\
\text { treatment }\end{array}$} & \multirow{2}{*}{$\begin{array}{l}\text { CB1R } \\
\text { activation }\end{array}$} & \multirow{2}{*}{$\begin{array}{l}\text { Treatment } \\
\text { duration }\end{array}$} & \multicolumn{4}{|c|}{ Functional readout } & \multirow[t]{2}{*}{ Ref } \\
\hline & & & & & $\begin{array}{l}\text { growth } \\
\text { cone } \\
\text { surface area }\end{array}$ & $\begin{array}{l}\text { number of extension } \\
\text { filopodia at rate } \\
\text { the growth cone }\end{array}$ & $\begin{array}{l}\text { neurite } \\
\text { out- } \\
\text { growth }\end{array}$ & $\begin{array}{l}\text { growth } \\
\text { cone turn- } \\
\text { ing angle }\end{array}$ & \\
\hline \multicolumn{10}{|l|}{ Bath application } \\
\hline \multirow{3}{*}{$\begin{array}{l}\text { Spontaneous } \\
\text { modifications of the } \\
\text { growth cone }\end{array}$} & retinal ganglion & DIV0 & ACEA & $24 \mathrm{~h}$ & - & - & & & 11 \\
\hline & cells (mouse) & & $50 \mathrm{nmol} / \mathrm{l}$ & & & & & & \\
\hline & $\begin{array}{l}\text { cortical neurons } \\
\text { (mouse) }\end{array}$ & DIV0 & $\begin{array}{l}\text { ACEA } \\
50 \mathrm{nmol} / 1\end{array}$ & $48 \mathrm{~h}$ & - & - & & & \\
\hline \multirow{5}{*}{$\begin{array}{l}\text { Electric field-induced } \\
\text { modifications of the } \\
\text { growth cone }\end{array}$} & spinal neu-rons & & AEA $10 \mathrm{nmol} / \mathrm{l}$ & $3 \mathrm{~h}$ & & & & - & 12 \\
\hline & (rat) & & AEA $100 \mathrm{nmol} / 1$ & $3 \mathrm{~h}$ & & & & - & \\
\hline & & & $\begin{array}{l}\text { WIN55,212-2 } \\
50 \mathrm{nmol} / 1\end{array}$ & $3 \mathrm{~h}$ & & & & - & \\
\hline & & & $\begin{array}{l}\text { WIN55,212-2 } \\
100 \mathrm{nmol} / \mathrm{l}\end{array}$ & $3 \mathrm{~h}$ & & & & - & \\
\hline & $\begin{array}{l}\text { cortical neurons } \\
\text { (rat) }\end{array}$ & $30 \mathrm{~h}$ & $\begin{array}{l}\text { JZL184 } \\
100 \mathrm{nmol} / \mathrm{l}\end{array}$ & $16 \mathrm{~h}$ & - & & & & 15 \\
\hline \multirow{3}{*}{$\begin{array}{l}\text { Microgradient } \\
\text { Spontaneous } \\
\text { modifications of the } \\
\text { growth cone }\end{array}$} & & & & & & & & & \\
\hline & $\begin{array}{l}\text { spinal neu-rons } \\
\text { (rat) }\end{array}$ & DIV2-3 & $\begin{array}{l}\text { WIN55,212-2 } \\
200 \mathrm{nmol} / \mathrm{l}\end{array}$ & $1 \mathrm{~h}$ & & & - & - & 12 \\
\hline & $\begin{array}{l}\text { retinal ganglion } \\
\text { cells (mouse) }\end{array}$ & DIV2 & $\begin{array}{l}\text { ACEA } \\
50 \mathrm{nmol} / 1\end{array}$ & $1 \mathrm{~h}$ & & & - & - & 11 \\
\hline
\end{tabular}

b CB1R inactivation

\begin{tabular}{|c|c|c|c|c|c|c|c|c|c|}
\hline & \multirow{2}{*}{$\begin{array}{l}\text { Cellular } \\
\text { model }\end{array}$} & \multirow{2}{*}{$\begin{array}{l}\text { DIV before } \\
\text { treatment }\end{array}$} & \multirow{2}{*}{$\begin{array}{l}\text { CB1R } \\
\text { inactivation }\end{array}$} & \multirow{2}{*}{$\begin{array}{l}\text { Treatment } \\
\text { duration }\end{array}$} & \multicolumn{4}{|c|}{ Functional readout } & \multirow[t]{2}{*}{ Ref. } \\
\hline & & & & & $\begin{array}{l}\text { growth } \\
\text { cone } \\
\text { surface area }\end{array}$ & $\begin{array}{l}\text { number of } \\
\text { filopodia at } \\
\text { the growth cone }\end{array}$ & $\begin{array}{l}\text { extension } \\
\text { rate }\end{array}$ & $\begin{array}{ll}\text { neurite } & \text { growth } \\
\text { out- } & \text { cone turn- } \\
\text { growth ing angle }\end{array}$ & \\
\hline \multirow{7}{*}{$\begin{array}{l}\text { Bath application } \\
\text { Spontaneous } \\
\text { modifications of the } \\
\text { growth cone }\end{array}$} & \multirow{3}{*}{$\begin{array}{l}\text { retinal neurons } \\
\text { (Xenopus) }\end{array}$} & & & & & & & & \\
\hline & & & $\begin{array}{l}\text { RHC-80267 } \\
500 \mu \mathrm{mol} / \mathrm{l}\end{array}$ & $30 \mathrm{~min}$ & & & $\begin{array}{l}- \\
\text { (only during } \\
\text { application) }\end{array}$ & & 112 \\
\hline & & & $\begin{array}{l}\text { RHC- } 80267 \\
250 \text { or } 500 \\
\mu \mathrm{mol} / 1\end{array}$ & $9 \mathrm{~h}$ & & & - & & \\
\hline & \multirow{2}{*}{$\begin{array}{l}\text { retinal ganglion } \\
\text { cells (mouse) }\end{array}$} & DIV0 & $\begin{array}{l}\text { AM-251 } \\
300 \mathrm{nmol} / \mathrm{l}\end{array}$ & $24 \mathrm{~h}$ & + & + & & & 11 \\
\hline & & DIV0 & $\begin{array}{l}\mathrm{O} 2050 \\
300 \mathrm{nmol} / \mathrm{l}\end{array}$ & $48 \mathrm{~h}$ & + & + & & & \\
\hline & \multirow{2}{*}{$\begin{array}{l}\text { cortical neurons } \\
\text { (mouse) }\end{array}$} & DIV0 & $\begin{array}{l}\mathrm{AM}-251 \\
300 \mathrm{nmol} / \mathrm{l}\end{array}$ & $48 \mathrm{~h}$ & + & + & & & \\
\hline & & DIV0 & $\begin{array}{l}\mathrm{O} 2050 \\
300 \mathrm{nmol} / 1\end{array}$ & $48 \mathrm{~h}$ & + & + & & & \\
\hline
\end{tabular}

This table summarizes the effects of direct modulation of CB1R activity on spontaneous or induced growth cone advance. The three articles that focus on the role of CB1R activity on growth cone navigation have shown that eCBs act as chemorepulsive cues for axonal growth cones. The ' + ' and '-' signs represent, respectively, statistically significant increase or decrease of the measured parameter as compared to control. 
ergic neurons, so the implication of the Erk signaling pathway remains unclear.

Overall, in vivo and in vitro studies have now clearly demonstrated that eCB signaling plays a central role in axonal pathfinding in the developing brain. Through the activation of CB1R, eCBs locally modulate growth cone morphology, motility and directionality in order to allow axons to reach their specific targets. However, the specific downstream molecular mechanisms underlying this process are still poorly described, and further research still needs to be performed to fully understand it.

\section{CB1R Activity Modulates the Establishment of Neuronal Connectivity}

Once pre- and postsynaptic elements have come into contact, both structures are modified in order to create a functional synapse. As CB1R is present both in growth cones and dendrites of developing neurons, several studies have investigated its role in the modulation of synaptogenesis $[7,12,13,15]$. cAMP/PKA activity, which has been proven instrumental to the induction of new synapses between hippocampal neurons in culture [94, 95], is expected to be inhibited by the $\mathrm{G}_{\mathrm{i} / \mathrm{o}}$-protein-coupled CB1R, suggesting that $\mathrm{CB1R}$ activation will result in reduced synaptogenesis. Indeed, cannabinoids were found to inhibit the formation of new synapses in cultured hippocampal neurons, induced by a forskolin-mediated increase in cAMP [13]. Similarly, in cultured cortical neurons, inhibition of DAGL $\alpha$ induces an increase in SNAP25 expression, strongly suggesting that inhibition of CB1R signaling triggers synaptogenesis [7]. These results were indirectly corroborated by in vivo findings, which showed that targeted deletion of CB1Rs in GABAergic neurons results in a significantly elevated density of perisomatic GABAergic terminals in the neocortex and hippocampus [12]. Collectively, these results depict CB1Rs as a negative regulator of synaptogenesis. This scenario was also indirectly confirmed by a recent study which showed that in growth cones reaching their target, the 2-AG degrading enzyme monoacylglycerol lipase (MGL), previously excluded from the advancing growth cone through proteosomal degradation, shows elevated concentrations [15]. As such downregulation of cell-autonomous $2-A G$ levels would result in diminished constitutive activation of CB1Rs, MGL-mediated release of the inhibitory CB1R-tone could be important for the initiation of synaptogenesis.

In conclusion, CB1Rs are likely negative regulators of the formation of new synapses. However, the bulk of the data was obtained through indirect methods; molecular mechanisms as well as the in vivo relevance of the inhibitory CB1R effect on synaptogenesis remain to be elucidated.

\section{eCBs, Surmountable Negative Regulators of Neurite Growth?}

The establishment of neuronal polarity depends on intrinsic factors and on extrinsic cues from the environment $[96,97]$, as proposed by Ramon Y Cajal more than a century ago, who observed that developing neurites resemble migrating cells, and thus neurite growth may be regulated by gradients of extracellular cues [98]. Recent models of gradient sensing and subsequent neuronal polarization propose a delicate balance between local stimulation, amplified by positive feed-back loops, and longrange diffusible inhibitory factors [96], whose integrated output may drive an excitable downstream network of cytoskeletal effectors [99]. Recent reports from the group of Mu-Ming Poo have started to formally identify key elements of the local-excitation, global-inhibition mechanism implicated in neuronal polarization by showing the antagonistic effects of the effectors cAMP/cGMP [100], regulated by multiple factors that are yet to be fully characterized, such as BDNF, a self-amplifying autocrine promoter of axon growth [101]. These reports depict a network of mutually inhibitory, competitive interactions during outgrowth of neural processes, both during axon specification and later during axon branching [102]. Consequently, an extrinsic factor may be a positive or a negative regulator of neurite growth, depending on the development stage, the identity of the neurite (axon or dendrite), and the presence or absence of other extrinsic factors, as it was shown for Semaphorin3A, a secreted factor which was reported to inhibit axonal growth and stimulate dendritic development [103]. Such dependence from the cellular and tissue context should be kept in mind by researchers who want to understand the action of cannabinoids on neurite development.

Based on these theoretical considerations and on the experimental data summarized above, we propose a new model which may help to untangle the complexity of experimental findings on $\mathrm{eCB}$ signaling on axonal growth and pathfinding (fig. 2). We propose that the primary effect of CB1R activation is the mobilization of cytoskeletal effectors such as Rho-activated kinase (ROCK), which are negatively coupled to cell spreading and neurite growth $[104,105]$. In consequence, the direct short-term effect of 
Fig. 2. Proposed model for eCBs as surmountable negative regulators of neurite growth. We propose that the primary effect of CB1R activation (blue arrows; colors refer to the online version only) is the mobilization of cytoskeletal effectors, which are negatively coupled to cell spreading and neurite growth. In most physiological contexts, cell-autonomous or paracrine activation of CB1Rs (CB) leads to a relatively moderate level of inhibition, which is surmountable by local growthpromoting factors (red arrows) at the growth cone, such as BDNF or netrin-1, resulting in more efficient polarized growth. However, when the growth cone reaches a region highly enriched with eCBs, the balance between eCB signaling and growthpromoting molecules would be modified, and could result, depending on the new equilibrium, in growth cone arrest, repulsion or collapse. Overall inhibition of this negative regulatory effect, e.g. through antagonist/inverse agonist (IA) ligands, leads to enhanced neurite growth, increased axonal branching and dendrite development. Arrow size is proportional to signal strength. $\mathrm{n}=$ neuronal nucleus.
Normal Growth

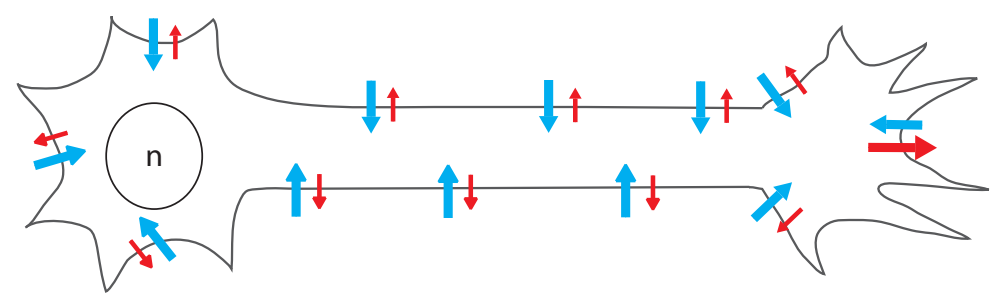

Bath application of CB1R agonist

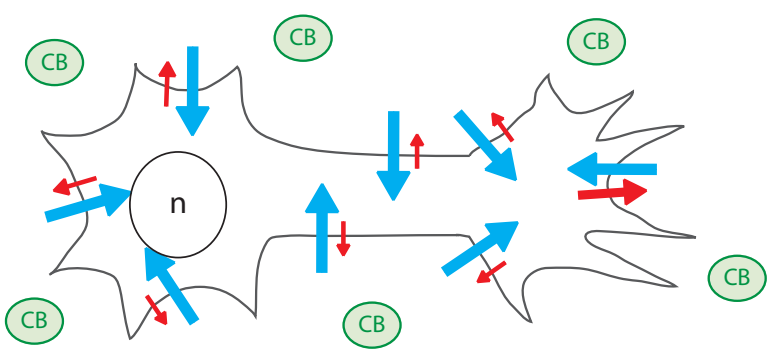

Local application of CB1R agonist

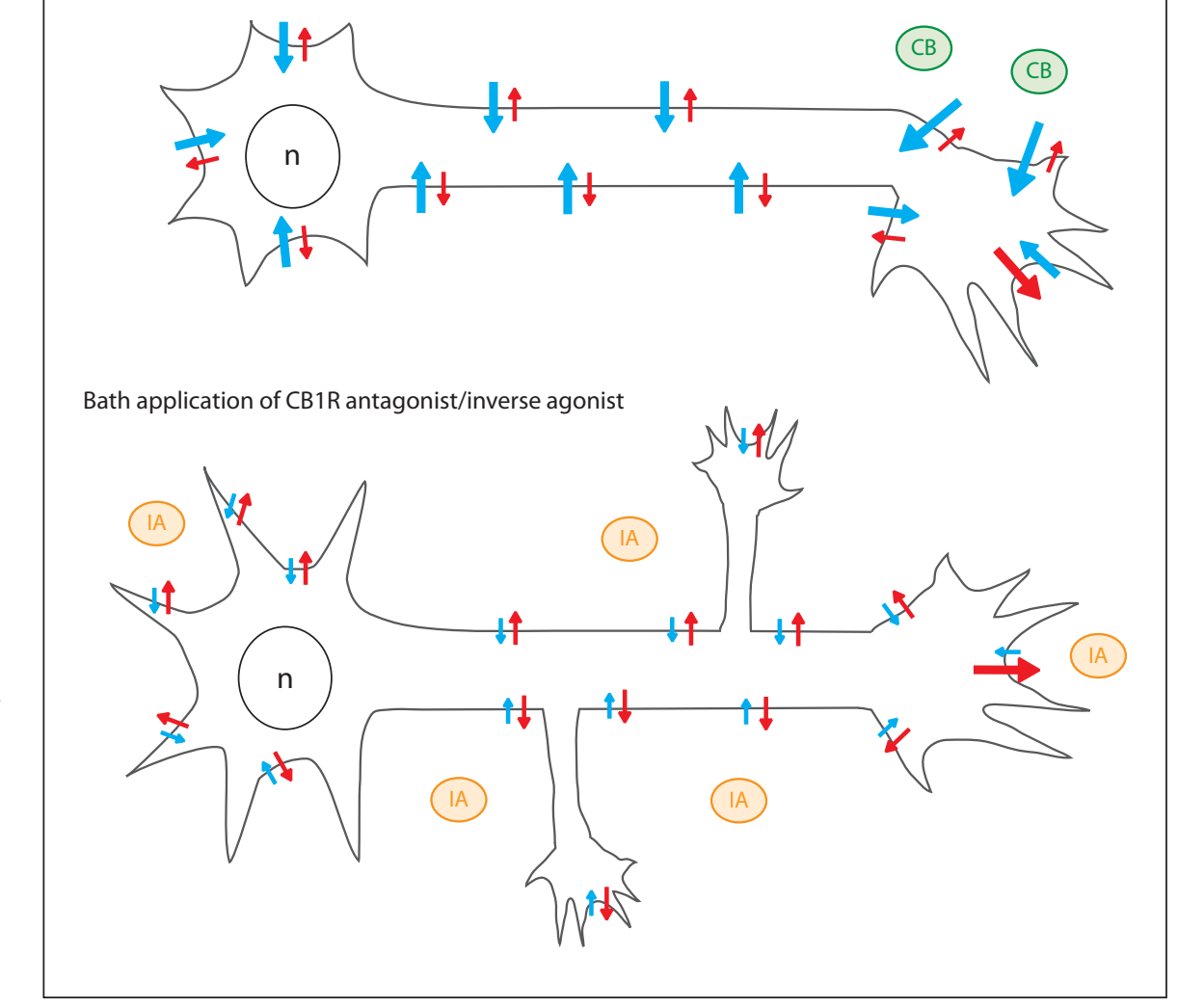

Bath application of CB1R antagonist/inverse agonist

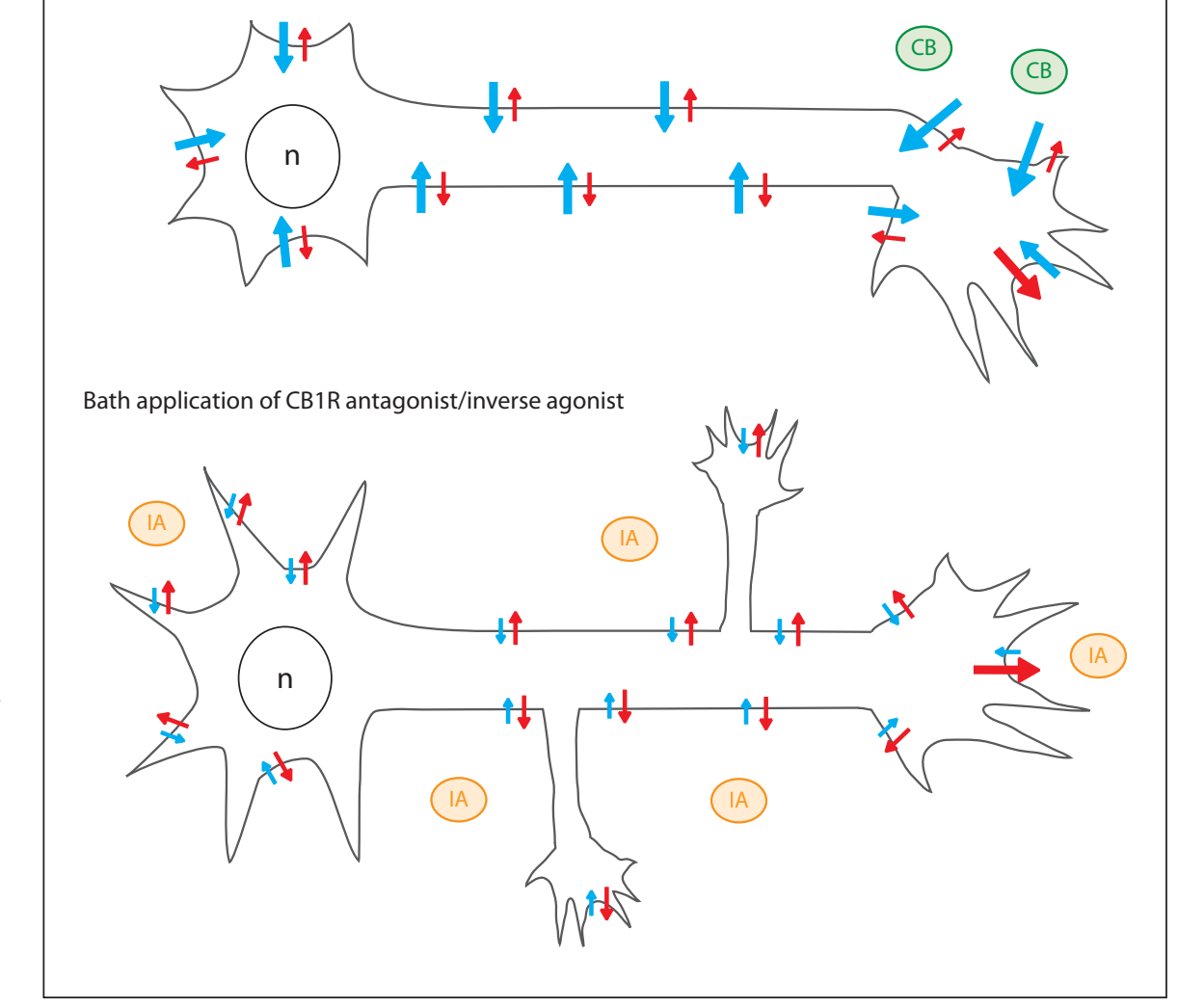


CB1R activation would be a principally negative effect on neurite growth. However, basal cell-autonomous or paracrine activation of CB1Rs would yield only relatively moderate inhibition in most physiological contexts, which is surmountable by local growth-promoting effectors at the growth cone, such as the self-amplifying autocrine promoter BDNF [101] or netrin-1 [11]. In such case, the 'channeling' effect of overall CB1R-mediated inhibition would help the neuron to focus its resources to a limited amount of growth sites, resulting in more efficient polarized growth. However, when the growth cone reaches a region highly enriched with eCBs, the balance between eCB signaling and growth-promoting molecules would be modified, and could result, depending on the new equilibrium, in growth cone arrest, repulsion or collapse. Notably, this system would be an efficient mechanism for coordinated guidance of axonal fascicles in the brain, where production of eCBs by nearby axons would be used as repulsion cues that allow axons to grow directly towards their target without unnecessary branching.

This model is based mainly on two principal cohorts of experimental findings which shed light on direct cellautonomous effects of CB1R activation. First, in the majority of neuroblastoma cell models, the most readily detected effect of CB1R activation, detected even at low agonist concentrations and short timescales, is cell rounding and neurite retraction. Second, direct observation of the effects of CB1R activation on growth cones consistently yielded cone arrest, repulsion or collapse at the timescale of minutes (table 2).

An important corollary to this model is that the activation of CB1Rs would be subject to fine spatial regulation. In the developing axon, it would display a constant and moderate level of activation, which would require the constant and local production of eCBs. This hypothesis is consistent with results from immunohistochemical studies, performed on the developing mouse brain, which reveal that DAGLs and CB1R are expressed in the same axonal tracts $[10,11,17]$ and in the same growth cones $[7$, 12]. That suggests that eCBs could be locally produced to activate CB1R in developing axons. Moreover, using ultrastructural analysis in E14-E16 mice, we have shown that while CB1Rs are present on the axonal plasma membrane, an important pool of receptors is found in axonal endosomes [8]. As the activation of the receptor has been clearly associated with its internalization [37-39, 106], this finding strongly suggests that axonal CB1R are continuously activated in the embryonic brain. Moreover, agonist treatment was shown to further increase the endosomal pool. Therefore, even if embryonic CB1R is sub- ject to significant basal activation, there is room for further axonal activation [8]. Taken together, in developing axons, there are several indirect indications that cell-autonomous and local production of eCBs leads to a basal and moderate activation of the receptor, which would be in line with our proposed model.

Overall, the above data argue in favor of controlled and mostly cell-autonomous basal activation of CB1Rs in developing axonal tracts. Unfortunately, detailed ontogenic profiling of DAGL $\alpha / \beta$ and MGL expression is currently lacking. However, the colocalization of DAGLs and CB1R diminishes in the postnatal cerebellum where DAGLs have been shown to be enriched in dendritic trees of Purkinje cells and excluded from CB1R enriched axonal tracts [17]. CB1R receptor localization also shows a developmentally regulated shift since in postnatal axons CB1Rs are mostly localized at the axonal plasma membrane $[35,36,73,107]$, whereas in the somatodendritic region they are mostly intracellular [36] because of constitutive endocytosis [38], partially due to somatodendritic DAGL action [48]. This somatodendritic endocytosis is important for the correct transcytotic targeting of CB1Rs to the axonal plasma membrane [38], but the exact mechanism of somatodendritic CB1R activation is still under debate [45]. These results collectively suggest that eCB-induced basal activation of axonal CB1Rs may be a developmentally regulated phenomenon. Direct measurements of CB1R activity levels at the sub-neuronal scale, a technically challenging task, may shed further light on this interesting question.

\section{Conclusions}

There is growing evidence that $\mathrm{eCB}$ signaling, through the activation of the CB1R plays a central role in neuronal development. Studies from developmental biology to cell biology, performed on several animal models, indicate that the fine regulation of this signaling pathway is important for sculpting the temporal and spatial diversity of neuronal networks during brain development. These developmental effects could, at least partially, explain the neurobehavioral abnormalities and the alteration of cognitive functions in marijuana-exposed offspring [108]. However, none of the available CB1R null mutant mice display a marked developmental CNS defect or clearly apparent behavioral phenotype. This robustness or resilience of CNS development, often described in rodent knock-out models, could be explained by redundancy at different levels: (1) at the cellular level, upstream signal- 
ing pathways converging on the same effectors as CB1Rs may show compensatory regulation, and (2) at the network level, the topology of CB1R-regulated neural networks may show elevated resilience towards the altered structural integrity of the network following deletion of hubs or links [109].

This review also emphasized the current lack of knowledge concerning the precise downstream signaling pathways involved in the effect of eCB system on neuronal development. Even if some key players have been identified, further identification of endocannabinoid ligands, metabolic enzymes or second-messenger cascades will be necessary to better understand the cellular context and microenvironmental requirements that drive the regulation of neuronal development by eCBs. For example, identifying the precise interactions of this pathway with cytoskeletal actors will give important clues to better understand the mechanisms that drive neuronal growth, migration or remodeling.

\section{Acknowledgments}

We are grateful to Natalia Velez-Sanchez (MIT, Boston, Mass.) for correction of the English syntax.

\section{References}

1 Matsuda LA, Lolait SJ, Brownstein MJ, Young AC, Bonner TI: Structure of a cannabinoid receptor and functional expression of the cloned CDNA. Nature 1990;346:561-564.

- 2 Freund TF, Hajos N: Excitement reduces inhibition via endocannabinoids. Neuron 2003;38:362-365.

- 3 Bacci A, Huguenard JR, Prince DA: Longlasting self-inhibition of neocortical interneurons mediated by endocannabinoids. Nature 2004;431:312-316.

$\checkmark 4$ Heifets BD, Castillo PE: Endocannabinoid signaling and long-term synaptic plasticity. Ann Rev Physiol 2009;71:283-306.

$\checkmark 5$ Begbie J, Doherty P, Graham A: Cannabinoid receptor, CB1, expression follows neuronal differentiation in the early chick embryo. J Anat 2004;205:213-218.

-6 Watson S, Chambers D, Hobbs C, Doherty P, Graham A: The endocannabinoid receptor, $\mathrm{CB} 1$, is required for normal axonal growth and fasciculation. Mol Cell Neurosci 2008; 38:89-97.

7 Mulder J, Aguado T, Keimpema E, Barabas K, Ballester Rosado CJ, Nguyen L, Monory K, Marsicano G, Di Marzo V, Hurd YL, Guillemot F, Mackie K, Lutz B, Guzman M, Lu HC, Galve-Roperh I, Harkany T: Endocannabinoid signaling controls pyramidal cell specification and long-range axon patterning. Proc Natl Acad Sci USA 2008;105:87608765.

$\checkmark 8$ Vitalis T, Laine J, Simon A, Roland A, Leterrier $\mathrm{C}$, Lenkei $\mathrm{Z}$ : The type 1 cannabinoid receptor is highly expressed in embryonic cortical projection neurons and negatively regulates neurite growth in vitro. Eur J Neurosci 2008;28:1705-1718. $\checkmark 9$ Gomez M, Hernandez ML, Pazos MR, Tolon RM, Romero J, Fernandez-Ruiz J: Colocalization of CB1 receptors with $\mathrm{L} 1$ and Gap-43 in forebrain white matter regions during fetal rat brain development. Evidence for a role of these receptors in axonal growth and guidance. Neuroscience 2008;153:687-699.

10 Wu CS, Zhu J, Wager-Miller J, Wang S, O’Leary D, Monory K, Lutz B, Mackie K, Lu $\mathrm{HC}$ : Requirement of cannabinoid $\mathrm{CB}(1)$ receptors in cortical pyramidal neurons for appropriate development of corticothalamic and thalamocortical projections. Eur J Neurosci 2010;32:693-706.

11 Argaw A, Duff G, Zabouri N, Cecyre B, Chaine N, Cherif H, Tea N, Lutz B, Ptito M, Bouchard JF: Concerted action of CB1 cannabinoid receptor and deleted in colorectal cancer in axon guidance. J Neurosci 2011;31: 1489-1499.

12 Berghuis P, Rajnicek AM, Morozov YM, Ross RA, Mulder J, Urban GM, Monory K, Marsicano G, Matteoli M, Canty A, Irving AJ, Katona I, Yanagawa Y, Rakic P, Lutz B, Mackie K, Harkany T: Hardwiring the brain: endocannabinoids shape neuronal connectivity. Science 2007;316:1212-1216.

13 Kim D, Thayer SA: Cannabinoids inhibit the formation of new synapses between hippocampal neurons in culture. J Neurosci 2001; 21:RC146.

-14 Bernard C, Milh M, Morozov YM, Ben-Ari Y, Freund TF, Gozlan H: Altering cannabinoid signaling during development disrupts neuronal activity. Proc Natl Acad Sci USA 2005;102:9388-9393.

15 Keimpema E, Barabas K, Morozov YM, Tortoriello G, Torii M, Cameron G, Yanagawa Y, Watanabe M, Mackie K, Harkany T: Differential subcellular recruitment of monoacylglycerol lipase generates spatial specificity of 2-arachidonoyl glycerol signaling during axonal pathfinding. J Neurosci 2010;30: 13992-14007.
6 Williams EJ, Walsh FS, Doherty P: The FGF receptor uses the endocannabinoid signaling system to couple to an axonal growth response. J Cell Biol 2003;160:481-486.

17 Bisogno T, Howell F, Williams G, Minassi A, Cascio MG, Ligresti A, Matias I, SchianoMoriello A, Paul P, Williams EJ, Gangadharan U, Hobbs C, Di Marzo V, Doherty P: Cloning of the first Sn1-Dag lipases points to the spatial and temporal regulation of endocannabinoid signaling in the brain. J Cell Biol 2003;163:463-468.

18 Berghuis P, Dobszay MB, Wang X, Spano S, Ledda F, Sousa KM, Schulte G, Ernfors P, Mackie K, Paratcha G, Hurd YL, Harkany T: Endocannabinoids regulate interneuron migration and morphogenesis by transactivating the TrkB receptor. Proc Natl Acad Sci USA 2005;102:19115-19120.

19 Zorina Y, Iyengar R, Bromberg KD: Cannabinoid 1 receptor and interleukin- 6 receptor together induce integration of protein kinase and transcription factor signaling to trigger neurite outgrowth. J Biol Chem 2010;285: 1358-1370.

20 Berrendero F, Sepe N, Ramos JA, Di Marzo V, Fernandez-Ruiz JJ: Analysis of cannabinoid receptor binding and mRNA expression and endogenous cannabinoid contents in the developing rat brain during late gestation and early postnatal period. Synapse 1999;33:181-191.

21 Turu G, Hunyady L: Signal transduction of the CB1 cannabinoid receptor. J Mol Endocrinol 2010;44:75-85.

22 Glass M, Felder CC: Concurrent stimulation of cannabinoid CB1 and dopamine D2 receptors augments cAMP accumulation in striatal neurons: evidence for a Gs linkage to the CB1 receptor. J Neurosci 1997; 17:5327-5333.

23 Childers SR, Deadwyler SA: Role of cyclic AMP in the actions of cannabinoid receptors. Biochem Pharmacol 1996;52:819-827. 
-24 Pan X, Ikeda SR, Lewis DL: Rat brain cannabinoid receptor modulates $\mathrm{N}$-type $\mathrm{Ca}^{2+}$ channels in a neuronal expression system. Mol Pharmacol 1996;49:707-714.

25 Kobilka BK, Deupi X: Conformational complexity of G-protein-coupled receptors. Trends Pharmacol Sci 2007;28:397-406.

-26 Rosenbaum DM, Rasmussen SGF, Kobilka BK: The structure and function of G-protein-coupled receptors. Nature 2009;459: 356-363.

-27 Ballesteros J, Palczewski K: G protein-coupled receptor drug discovery. Implications from the crystal structure of rhodopsin. Curr Opin Drug Discov Devel 2001;4:561574.

-28 Shapiro DA, Kristiansen K, Weiner DM, Kroeze WK, Roth BL: Evidence for a model of agonist-induced activation of 5-hydroxytryptamine 2 a serotonin receptors that involves the disruption of a strong ionic interaction between helices 3 and 6 . J Biol Chem 2002;277:18244-18244.

-29 Seifert R, Wenzel-Seifert K: Constitutive activity of G-protein-coupled receptors: cause of disease and common property of wildtype receptors. Naunyn Schmiedebergs Arch Pharmacol 2002;366:381-416.

30 Bouaboula M, Perrachon S, Milligan L, Canat X, Rinaldi-Carmona M, Portier M, Barth F, Calandra B, Pecceu F, Lupker J, Maffrand JP, Le Fur G, Casellas P: A selective inverse agonist for central cannabinoid receptor inhibits mitogen-activated protein kinase activation stimulated by insulin or insulin-like growth factor 1. Evidence for a new model of receptor/ligand interactions. J Biol Chem 1997;272:22330-22339.

-31 Pan X, Ikeda SR, Lewis DL: Sr 141716a acts as an inverse agonist to increase neuronal voltage-dependent $\mathrm{Ca}^{2+}$ currents by reversal of tonic cb1 cannabinoid receptor activity. Mol Pharmacol 1998;54:1064-1072.

-32 Hillard CJ, Muthian S, Kearn CS: Effects of $\mathrm{CB}(1)$ cannabinoid receptor activation on cerebellar granule cell nitric oxide synthase activity. FEBS Lett 1999;459:277-281.

-33 Ballesteros J, Kitanovic S, Guarnieri F, Davies P, Fromme BJ, Konvicka K, Chi L, Millar RP, Davidson JS, Weinstein H, Sealfon SC: Functional microdomains in G-proteincoupled receptors - the conserved argininecage motif in the gonadotropin-releasing hormone receptor. J Biol Chem 1998;273: 10445-10453.

-34 D'antona AM, Ahn KH, Kendall DA: Mutations of $\mathrm{CB} 1 \mathrm{t} 210$ produce active and inactive receptor forms. Correlations with ligand affinity, receptor stability, and cellular localization. Biochemistry 2006;45:5606-5617.

-35 Katona I, Rancz EA, Acsady L, Ledent C, Mackie K, Hajos N, Freund TF: Distribution of CB1 cannabinoid receptors in the amygdala and their role in the control of GABAergic transmission. J Neurosci 2001;21:95069518.
36 Bodor AL, Katona I, Nyiri G, Mackie K, Ledent C, Hajos N, Freund TF: Endocannabinoid signaling in rat somatosensory cortex: laminar differences and involvement of specific interneuron types. J Neurosci 2005;25: 6845-6856.

37 Coutts AA, Anavi-Goffer S, Ross RA, MacEwan DJ, Mackie K, Pertwee RG, Irving AJ: Agonist-induced internalization and trafficking of cannabinoid $\mathrm{CB}(1)$ receptors in hippocampal neurons. J Neurosci 2001;21: 2425-2433.

38 Leterrier C, Laine J, Darmon M, Boudin H, Rossier J, Lenkei Z: Constitutive activation drives compartment-selective endocytosis and axonal targeting of type 1 cannabinoid receptors. J Neurosci 2006;26:3141-3153.

39 Leterrier C, Bonnard D, Carrel D, Rossier J, Lenkei Z: Constitutive endocytic cycle of the CB1 cannabinoid receptor. J Biol Chem 2004; 279:36013-36021.

40 Ellis J, Pediani JD, Canals M, Milasta S, Milligan G: Orexin-1 receptor-cannabinoid CB1 receptor heterodimerization results in both ligand-dependent and -independent coordinated alterations of receptor localization and function. J Biol Chem 2006;281:38812-38824.

-41 Tappe-Theodor A, Agarwal N, Katona I, Rubino T, Martini L, Swiercz J, Mackie K, Monyer H, Parolaro D, Whistler J, Kuner T, Kuner R: A molecular basis of analgesic tolerance to cannabinoids. J Neurosci 2007;27: 4165-4177.

- 42 Wu DF, Yang LQ, Goschke A, Stumm R, Brandenburg LO, Liang YJ, Hollt V, Koch T: Role of receptor internalization in the agonist-induced desensitization of cannabinoid type 1 receptors. J Neurochem 2008;104: 1132-1143.

43 Rozenfeld R, Devi LA: Regulation of CB1 cannabinoid receptor trafficking by the adaptor protein AP-3. FASEB J 2008;22: 2311-2322.

44 Grimsey NL, Graham ES, Dragunow M, Glass M: Cannabinoid receptor 1 trafficking and the role of the intracellular pool: implications for therapeutics. Biochem Pharmacol 2010;80:1050-1062.

45 McDonald NA, Henstridge CM, Connolly CN, Irving AJ: An essential role for constitutive endocytosis, but not activity, in the axonal targeting of the CB1 cannabinoid receptor. Mol Pharmacol 2007;71:976-984.

-46 Benard G, Massa F, Puente N, Lourenco J, Bellocchio L, Soria-Gomez E, Matias I, Delamarre A, Metna-Laurent M, Cannich A, Hebert-Chatelain E, Mulle C, Ortega-Gutierrez S, Martin-Fontecha M, Klugmann M, Guggenhuber S, Lutz B, Gertsch J, Chaouloff F, Lopez-Rodriguez ML, Grandes P, Rossignol R, Marsicano G: Mitochondrial CB(1) receptors regulate neuronal energy metabolism. Nat Neurosci 2012;15:558-564.
47 Carrel D, Simon A, Emerit MB, Rivals I, Leterrier C, Biard M, Hamon M, Darmon M, Lenkei Z: Axonal targeting of the 5-HT1b serotonin receptor relies on structure-specific constitutive activation. Traffic 2011;12: 1501-1520.

48 Turu G, Simon A, Gyombolai P, Szidonya L, Bagdy G, Lenkei Z, Hunyady L: The role of diacylglycerol lipase in constitutive and angiotensin AT1 receptor-stimulated cannabinoid CB1 receptor activity. J Biol Chem 2007; 282:7753-7757.

49 Mohammad S, Baldini G, Granell S, Narducci P, Martelli AM: Constitutive traffic of melanocortin-4 receptor in neuro2a cells and immortalized hypothalamic neurons. J Biol Chem 2007;282:4963-4974.

50 Marion S, Weiner DM, Caron MG: RNA editing induces variation in desensitization and trafficking of 5-hydroxytryptamine 2C receptor isoforms. J Biol Chem 2004;279: 2945-2954.

51 Chanrion B, Mannoury la Cour C, Gavarini S, Seimandi M, Vincent L, Pujol JF, Bockaert J, Marin P, Millan MJ: Inverse agonist and neutral antagonist actions of antidepressants at recombinant and native 5-hydroxytryptamine2C receptors. Differential modulation of cell surface expression and signal transduction. Mol Pharmacol 2008;73:748757.

52 Whistler JL, Enquist J, Marley A, Fong J, Gladher F, Tsuruda P, Murray SR, Von Zastrow M: Modulation of postendocytic sorting of g protein-coupled receptors. Science 2002;297:615-620.

53 Morris DP, Price RR, Smith MP, Lei B, Schwinn DA: Cellular trafficking of human alphala-adrenergic receptors is continuous and primarily agonist-independent. Mol Pharmacol 2004;66:843-854.

54 Morisset S, Rouleau A, Ligneau X, Gbahou F, Tardivel-Lacombe J, Stark H, Schunack W, Ganellin CR, Schwartz JC, Arrang JM: High constitutive activity of native $\mathrm{H} 3$ receptors regulates histamine neurons in brain. $\mathrm{Na}$ ture 2000;408:860-864.

$\checkmark 55$ Holliday ND, Holst B, Rodionova EA, Schwartz TW, Cox HM: Importance of constitutive activity and arrestin-independent mechanisms for intracellular trafficking of the ghrelin receptor. Mol Endocrinol 2007; 21:3100-3112.

56 Jacquier V, Prummer M, Segura JM, Pick H, Vogel H: Visualizing odorant receptor trafficking in living cells down to the singlemolecule level. Proc Natl Acad Sci USA 2006; 103:14325-14330.

57 Howlett AC, Reggio PH, Childers SR, Hampson RE, Ulloa NM, Deutsch DG: Endocannabinoid tone versus constitutive activity of cannabinoid receptors. Br J Pharmacol 2011; 163:1329-1343. 
58 Pertwee RG, Howlett AC, Abood ME, Alexander SPH, Di Marzo V, Elphick MR, Greasley PJ, Hansen HS, Kunos G, Mackie K, Mechoulam R, Ross RA: International union of basic and clinical pharmacology. LXXIX. Cannabinoid receptors and their ligands: beyond $\mathrm{CB}(1)$ and $\mathrm{CB}(2)$. Pharmacol Rev 2010;62:588-631.

59 Alger BE, Kim J: Supply and demand for endocannabinoids. Trends Neurosci 2011;34: 304-315.

-60 Devane WA, Hanus L, Breuer A, Pertwee RG, Stevenson LA, Griffin G, Gibson D, Mandelbaum A, Etinger A, Mechoulam R: Isolation and structure of a brain constituent that binds to the cannabinoid receptor. Science 1992;258:1946-1949.

-61 Sugiura T, Kondo S, Sukagawa A, Nakane S, Shinoda A, Itoh K, Yamashita A, Waku K: 2-Arachidonoylgylcerol - a possible endogenous cannabinoid receptor-ligand in brain. Biochem Biophys Res Commun 1995;215: 89-97.

62 Bisogno T, Ligresti A, Di Marzo V: The endocannabinoid signalling system. Biochemical aspects. Pharmacol Biochem Behav 2005; 81:224-238.

63 D’antona AM, Ahn KH, Wang L, Mierke DF, Lucas-Lenard J, Kendall DA: A cannabinoid receptor 1 mutation proximal to the dry motif results in constitutive activity and reveals intramolecular interactions involved in receptor activation. Brain Res 2006;1108:1-11.

64 Pertwee RG: Inverse agonism and neutral antagonism at cannabinoid $\mathrm{CB1}$ receptors. Life Sci 2005;76:1307-1324.

65 Oates J, Watts A: Uncovering the intimate relationship between lipids, cholesterol and GPCR activation. Curr Opin Struct Biol 2011;21:802-807.

66 Phillips R, Ursell T, Wiggins P, Sens P: Emerging roles for lipids in shaping membrane-protein function. Nature 2009;459: 379-385.

67 Mátyás F, Yanovsky Y, Mackie K, Kelsch W, Misgeld U, Freund TF: Subcellular localization of type 1 cannabinoid receptors in the rat basal ganglia. Neuroscience 2006;137(1): 337-361.

68 Starke K: Presynaptic receptors. Annu Rev Pharmacol Toxicol 1981;21:7-30.

69 Herkenham M, Lynn AB, Johnson MR, Melvin LS, de Costa BR, Rice KC: Characterization and localization of cannabinoid receptors in rat brain. A quantitative in vitro autoradiographic study. J Neurosci 1991;11: 563-583.

70 Romero J, Garcia-Palomero E, Berrendero F, Garcia-Gil L, Hernandez ML, Ramos JA, Fernandez-Ruiz JJ: Atypical location of cannabinoid receptors in white matter areas during rat brain development. Synapse 1997; 26:317-323.
71 Berrendero F, Garcia-Gil L, Hernandez ML, Romero J, Cebeira M, de Miguel R, Ramos JA, Fernandez-Ruiz JJ: Localization of mRNA expression and activation of signal transduction mechanisms for cannabinoid receptor in rat brain during fetal development. Development 1998;125:3179-3188

72 Wang X, Dow-Edwards D, Keller E, Hurd YL: Preferential limbic expression of the cannabinoid receptor mrna in the human fetal brain. Neuroscience 2003;118:681-694.

73 Morozov YM, Freund TF: Post-natal development of type 1 cannabinoid receptor immunoreactivity in the rat hippocampus. Eur J Neurosci 2003;18:1213-1222.

74 Marin O, Rubenstein JLR: Cell migration in the forebrain. Ann Rev Neurosci 2003;26: 441-483.

75 Rueda D, Navarro B, Martinez-Serrano A, Guzman M, Galve-Roperh I: The endocannabinoid anandamide inhibits neuronal progenitor cell differentiation through attenuation of the Rap1/B-Raf/ERK pathway. J Biol Chem 2002;277:46645-46650.

76 Aguado T, Monory K, Palazuelos J, Stella N, Cravatt B, Lutz B, Marsicano G, Kokaia Z, Guzman M, Galve-Roperh I: The endocannabinoid system drives neural progenitor proliferation. FASEB J 2005;19:1704-1706.

77 Jin K, Xie L, Kim SH, Parmentier-Batteur S, Sun Y, Mao XO, Childs J, Greenberg DA: Defective adult neurogenesis in CB1 cannabinoid receptor knockout mice. Mol Pharmacol 2004;66:204-208.

78 Jiang W, Zhang Y, Xiao L, Van Cleemput J, Ji SP, Bai G, Zhang X: Cannabinoids promote embryonic and adult hippocampus neurogenesis and produce anxiolytic- and antidepressant-like effects. J Clin Invest 2005; 115: 3104-3116.

79 Aguado T, Palazuelos J, Monory K, Stella N, Cravatt B, Lutz B, Marsicano G, Kokaia Z, Guzman M, Galve-Roperh I: The endocannabinoid system promotes astroglial differentiation by acting on neural progenitor cells. J Neurosci 2006;26:1551-1561.

80 Molina-Holgado E, Vela JM, Arevalo-Martin A, Almazan G, Molina-Holgado F, Borrell J, Guaza C: Cannabinoids promote oligodendrocyte progenitor survival: in volvement of cannabinoid receptors and phosphatidylinositol-3 kinase/Akt signaling. J Neurosci 2002;22:9742-9753.

81 Wolf SA, Bick-Sander A, Fabel K, Leal-Galicia P, Tauber S, Ramirez-Rodriguez G, Muller A, Melnik A, Waltinger TP, Ullrich O, Kempermann G: Cannabinoid receptor CB1 mediates baseline and activity-induced survival of new neurons in adult hippocampal neurogenesis. Cell Commun Signal 2010;8:12.

82 Soltys J, Yushak M, Mao-Draayer Y: Regulation of neural progenitor cell fate by anandamide. Biochem Biophys Res Commun 2010;400:21-26.
83 Sideris A, Bekker T, Chan WS, MontoyaGacharna JV, Blanck TJ, Recio-Pinto E: A role for the cannabinoid 1 receptor in neuronal differentiation of adult spinal cord progenitors in vitro is revealed through pharmacological inhibition and genetic deletion. Front Neurosci 2012;6:4.

84 Oudin MJ, Gajendra S, Williams G, Hobbs C, Lalli G, Doherty P: Endocannabinoids regulate the migration of subventricular zone-derived neuroblasts in the postnatal brain. J Neurosci 2011;31:4000-4011.

85 Kriegstein A, Alvarez-Buylla A: The glial nature of embryonic and adult neural stem cells. Ann Rev Neurosci 2009;32:149-184.

86 Banker G, Goslin K: Culturing Nerve Cells. Cambridge, MIT Press, 1991.

>87 Cabral GA, Mcnerney PJ, Mishkin EM: Interaction of delta-9-tetrahydrocannabinol with rat B103 neuroblastoma-cells. Arch Toxicol 1987;60:438-449.

$>88$ Ishii I, Chun J: Anandamide-induced neuroblastoma cell rounding via the CB1 cannabinoid receptors. Neuroreport 2002;13:593596.

89 Zhou D, Song ZH: CB1 cannabinoid receptor-mediated neurite remodeling in mouse neuroblastoma N1e-115 cells. J Neurosci Res 2001;65:346-353.

90 Chemin J, Nargeot J, Lory P: Neuronal Ttype alpha $1 \mathrm{H}$ calcium channels induce neuritogenesis and expression of high-voltageactivated calcium channels in the NG108-15 cell line. Journal of Neuroscience 2002;22: 6856-6862.

-91 Jung KM, Astarita G, Thongkham D, Piomelli D: Diacylglycerol lipase-alpha and -beta control neurite outgrowth in neuro-2a cells through distinct molecular mechanisms. Mol Pharmacol 2011;80:60-67.

-92 He JC, Gomes I, Nguyen T, Jayaram G, Ram PT, Devi LA, Iyengar R: The G alpha(o/ i)-coupled cannabinoid receptor-mediated neurite outgrowth involves Rap regulation of Src and Stat3. J Biol Chem 2005;280: 33426-33434.

93 Jordan JD, He JC, Eungdamrong NJ, Gomes I, Ali W, Nguyen T, Bivona TG, Philips MR, Devi LA, Iyengar R: Cannabinoid receptorinduced neurite outgrowth is mediated by Rap1 activation through G(alpha)o/i-triggered proteasomal degradation of RaplGapII. J Biol Chem 2005;280:11413-11421.

-94 Kavalali ET, Klingauf J, Tsien RW: Activitydependent regulation of synaptic clustering in a hippocampal culture system. Proc Natl Acad Sci USA 1999;96:12893-12900.

$\checkmark 95$ Ma L, Zablow L, Kandel ER, Siegelbaum SA: Cyclic AMP induces functional presynaptic boutons in hippocampal CA3-CA1 neuronal cultures. Nat Neurosci 1999;2:24-30. 
96 Arimura N, Kaibuchi K: Neuronal polarity: from extracellular signals to intracellular mechanisms. Nat Rev Neurosci 2007;8: 194-205.

$\checkmark 97$ Barnes AP, Solecki D, Polleux F: New sights into the molecular mechanisms specifying neuronal polarity in vivo. Curr Opin Neurobiol 2008; 18:44-52.

$\checkmark 98$ Cajal Y, Berg OG, Jain MK: Direct vesiclevesicle exchange of phospholipids mediated by polymyxin B. Biochem Biophys Res Commun 1995;210:746-752.

$\checkmark 99$ Xiong YA, Huang CH, Iglesias PA, Devreotes PN: Cells navigate with a localexcitation, global-inhibition-biased excitable network. Proc Natl Acad Sci USA 2010; 107:17079-17086.

100 Shelly M, Lim BK, Cancedda L, Heilshorn SC, Gao HF, Poo MM: Local and longrange reciprocal regulation of cAMP and cGMP in axon/dendrite formation. Science 2010;327:547-552.

-101 Cheng PL, Song AH, Wong YH, Wang S, Zhang X, Poo MM: Self-amplifying autocrine actions of BDNF in axon development. Proc Natl Acad Sci USA 2011;108: 18430-18435.
102 Hutchins BI: Competitive outgrowth of neural processes arising from long-distance cAMP signaling. Sci Signal 2010; 3:jc1.

103 Shelly M, Cancedda L, Lim BK, Popescu AT, Cheng PL, Gao HF, Poo MM: Semaphorin3a regulates neuronal polarization by suppressing axon formation and promoting dendrite growth. Neuron 2011;71:433-446.

104 Dickson BJ: Rho GTPases in growth cone guidance. Curr Opin Neurobiol 2001;11: 103-110.

105 Luo L: Rho GTPases in neuronal morphogenesis. Nat Rev Neurosci 2000;1:173-180.

106 Hsieh C, Brown S, Derleth C, Mackie K: Internalization and recycling of the CB1 cannabinoid receptor. J Neurochem 1999;73: 493-501.

107 Nyiri G, Cserep C, Szabadits E, Mackie K, Freund TF: CB-1 cannabinoid receptors are enriched in the perisynaptic annulus and on preterminal segments of hippocampal GABAergic axons. Neuroscience 2005; 136: 811-822.
108 Huizink AC, Mulder EJH: Maternal smoking, drinking or cannabis use during pregnancy and neurobehavioral and cognitive functioning in human offspring. Neurosci Biobehav Rev 2006;30:24-41.

109 Bullmore E, Sporns O: Complex brain networks. Graph theoretical analysis of structural and functional systems. Nat Rev Neurosci 2009; 10:186.

110 Aguado T, Romero E, Monory K, Palazuelos J, Sendtner M, Marsicano G, Lutz B, Guzman M, Galve-Roperh I: The CB1 cannabinoid receptor mediates excitotoxicityinduced neural progenitor proliferation and neurogenesis. J Biol Chem 2007;282: 23892-23898.

111 Krebs-Kraft DL, Hill MN, Hillard CJ, McCarthy MM: Sex difference in cell proliferation in developing rat amygdala mediated by endocannabinoids has implications for social behavior. Proc Natl Acad Sci USA 2010;107:20535-20540.

112 Lom B, Hopker V, McFarlane S, Bixby JL, Holt CE: Fibroblast growth factor receptor signaling in Xenopus retinal axon extension. J Neurobiol 1998;37:633-641. 